University of Wollongong

Research Online

Faculty of Engineering and Information

Faculty of Engineering and Information

Sciences - Papers: Part B

Sciences

2018

Investigation on the Behaviour of Partial Wrapping in Comparison with Full Wrapping of Square RC Columns under Different Loading Conditions

Anh Duc Mai

University of Wollongong, mad766@uowmail.edu.au

M Neaz Sheikh

University of Wollongong, msheikh@uow.edu.au

Muhammad N. S Hadi

University of Wollongong, mhadi@uow.edu.au

Follow this and additional works at: https://ro.uow.edu.au/eispapers1

Part of the Engineering Commons, and the Science and Technology Studies Commons

Research Online is the open access institutional repository for the University of Wollongong. For further information contact the UOW Library: research-pubs@uow.edu.au 


\title{
Investigation on the Behaviour of Partial Wrapping in Comparison with Full Wrapping of Square RC Columns under Different Loading Conditions
}

\author{
Abstract \\ This study investigates the behaviour of square reinforced concrete (RC) columns partially and fully \\ wrapped with CFRP under different loading conditions. The experimental results of twelve specimens \\ with $150 \mathrm{~mm} \times 150 \mathrm{~mm}$ cross-section and $800 \mathrm{~mm}$ height tested under concentric axial load, eccentric \\ axial loads and four-point bending are presented in this study. The experimental results showed that \\ partial and full wrapping increased the strength and ductility of square RC column specimens. The \\ increase in the strength and ductility of fully wrapped square RC column specimens was higher than the \\ increase in the strength and ductility of partially wrapped square RC column specimens under all loading \\ conditions. However, the increase in the axial load eccentricity (concentric, 25 mmeccentric and 50 \\ mmeccentric axial loads) resulted in a significant decrease in the maximum axial load with the largest \\ reduction observed for fully wrapped specimens compared to partially wrapped specimens. The \\ experimental axial load-bending moment interaction diagrams showed the better performance of partially \\ and fully CFRP wrapped square RC specimens compared to non-wrapped square RC specimens.

\section{Disciplines} \\ Engineering | Science and Technology Studies

\section{Publication Details} \\ Mai, A., Sheikh, M. Neaz. \& Hadi, M. N. S. (2018). Investigation on the Behaviour of Partial Wrapping in \\ Comparison with Full Wrapping of Square RC Columns under Different Loading Conditions. Construction \\ and Building Materials, 168 153-168.
}


$4 \quad{ }^{1}$ Ph.D. Candidate, School of Civil, Mining and Environmental Engineering, University

5 of Wollongong, Wollongong, NSW 2522, Australia.E-mail: mad766@uowmail.edu.au

$6{ }^{2}$ Associate Professor, School of Civil, Mining and Environmental Engineering,

7 University of Wollongong, Wollongong, NSW 2522, Australia. E-mail:

8 msheikh@uow.edu.au

$9{ }^{3}$ Associate Professor, School of Civil, Mining and Environmental Engineering,

\section{Wrapping of Square RC Columns under Different Loading Conditions}

Anh Duc Mai ${ }^{1}$, M. Neaz Sheikh ${ }^{2}$, Muhammad N.S. Hadi ${ }^{3}$ University of Wollongong, Wollongong, NSW 2522, Australia (corresponding author). E-mail:mhadi@uow.edu.au

\section{ABSTRACT}

This study investigates the behaviour of square reinforced concrete (RC) columns partially and fully wrapped with CFRP under different loading conditions. The experimental results of twelve specimens with $150 \mathrm{~mm}$ x $150 \mathrm{~mm}$ cross-section and 800 mm height tested under concentric axial load, eccentric axial loads and four-point bending are presented in this study. The experimental results showed that partial and full wrapping increased the strength and ductility of square RC column specimens. The increase in the strength and ductility of fully wrapped square RC column specimens was higher than the increase in the strength and ductility of partially wrapped square RC column specimens under all loading conditions. However, the increase in the axial load eccentricity (concentric, $25 \mathrm{~mm}$ eccentric and $50 \mathrm{~mm}$ eccentric axial loads) resulted in a 
significant decrease in the maximum axial load with the largest reduction observed for fully wrapped specimens compared to partially wrapped specimens. The experimental axial load-bending moment interaction diagrams showed the better performance of partially and fully CFRP wrapped square RC specimens compared to non-wrapped square RC specimens.

Keywords: Square columns; Carbon fibre; Partial wrapping; Full wrapping; Concentric axial load; Eccentric axial load; Flexural load; Ductility.

\section{Introduction}

32 Strengthening of existing deficient structural members has become a critical issue for the construction industry due to the deterioration of the structures under severe environmental conditions, increase in the load demand and the change of the structural functions [1-3]. Fibre Reinforced Polymers (FRPs) have emerged as efficient materials for strengthening deficient structural members during the past few decades. The FRP has been widely used due to its superior engineering properties including high tensile strength and stiffness, high strength-to-weight ratio, and high corrosion resistance $[1,2$, 4-7].

Transverse wrapping of concrete columns with FRP inhibits the lateral expansion of concrete leading to substantial enhancements in the strength and ductility of the columns [5, 8-14]. Most of the available research studies investigated the performance of fully FRP wrapped columns [5, 8, 10, 15-22]. However, only a few studies investigated the behaviour of partially FRP wrapped cylinders and prisms [23-27] and RC columns [28-40]. It was reported that partial FRP wrapping improved the strength and ductility of the RC columns [28-38]. Partial wrapping has some practical 
47 advantages compared to full wrapping. Partial wrapping can prevent the formation of possible air-voids between the FRP and the concrete surface [24]. It is cost-effective because less FRP and adhesive are required [36] and easy and fast to construct on site [24]. Partial wrapping is also an efficient way to repair the deteriorated RC columns [41]. Partial wrapping could be an efficient and economical choice for RC columns which are in need of a moderate increase in the strength and ductility. However, ACI 440.2R-17 [2] has not yet provided guidelines for the partial wrapping in strengthening compression members due to inadequate research on the partial wrapping of $\mathrm{RC}$ columns. Hence, the behaviour of partially FRP wrapped RC columns needs to be extensively investigated.

In practice, $\mathrm{RC}$ columns are subjected to combined axial compression and bending moments. The bending moment may be induced due to the position of the columns in the structure, out of straightness of the constructed columns, and unintentional eccentric axial loads [42]. The increase in axial load eccentricity leads to a reduction in the FRP confined area of the columns. Consequently, the confinement effect is less for eccentrically loaded RC columns than for concentrically loaded RC columns [5, 9, 18, $19,21,32,40,43-46]$.

The effectiveness of FRP confinement is influenced by the cross-sectional shape of the columns. The FRP confinement effect is much lower for non-circular cross-sections than for circular cross-sections [1, 3, 47-55]. This is because the confinement pressure is non-uniform across the non-circular cross-section compared to the uniform confinement pressure across the circular cross-section. The behaviour of partially FRP wrapped square RC columns was only investigated in a limited number of studies [29-34, 36, 
40]. These studies examined the performance of partially FRP wrapped square RC columns under either pure axial load [36, 40] or eccentric axial loads [29-31] or seismic loads [34]. Only a few studies investigated partially FRP wrapped square RC columns under both concentric and eccentric axial loads [32, 33]. It is noted that the partially CFRP wrapped square RC specimens investigated in Saljoughian and Mostofinejad [32, 33] had the corner radii of $8 \mathrm{~mm}$, which is significantly lower than the corner radius recommended in ACI 440.2R-17 [2] of $13 \mathrm{~mm}$ and in FIB bulletin 14 [56] of $20 \mathrm{~mm}$. In addition, the available studies on the partial wrapping of square RC columns did not adequately compare the behaviour of partially FRP wrapped square RC column with the behaviour of fully FRP wrapped square RC columns. However, Barros and Ferreira [23], Pham, et al. [25] and Campione, et al. [27] experimentally investigated the behaviour of partially FRP wrapped concrete cylinders with the behaviour of fully FRP wrapped concrete cylinders under axial compression. The experimental results indicated that the increase in the compressive strength of partially wrapped concrete cylinders was lower than the increase in the compressive strength of fully wrapped concrete cylinders. However, partial wrapping resulted in a higher compressive strength and axial deformation compared to non-wrapped specimens [23, 25]. Therefore, for a better understanding of the strength and ductility enhancement of partial wrapping, the behaviour of partially FRP wrapped square RC columns should be extensively studied and compared with the behaviour of fully FRP wrapped square RC columns.

It is evident from the above literature review that the behaviour of partially FRP wrapped square RC columns under concentric and eccentric axial loads have not been adequately investigated. Therefore, the aim of this study is to experimentally investigate the performance of partially CFRP wrapped square RC columns under different loading 
94 conditions in comparison with fully CFRP wrapped square RC columns. The main parameters investigated in this study included wrapping schemes (non-wrapping, partial wrapping and full wrapping) and the magnitude of load eccentricity (concentric axial load, eccentric axial loads, and four-point bending). Theoretical investigation on the performance of partially CFRP wrapped square RC columns is considered beyond the scope of the paper.

\section{Experimental program}

\subsection{Design of specimens}

The test matrix consisted of 12 square RC specimens of $150 \mathrm{~mm}$ x $150 \mathrm{~mm}$ crosssection and $800 \mathrm{~mm}$ height. The specimens were divided into three groups including reference group (Group R), partial wrapping group (Group P), and full wrapping group (Group F). Each group included four specimens. The first three specimens were tested as columns under concentric axial load, $15 \mathrm{~mm}$ eccentric axial load and $25 \mathrm{~mm}$ eccentric axial load. The last specimen of each group was tested as a beam under fourpoint bending. The beam specimens were flexural dominant. The dimension of the specimens was chosen to simulate the short columns according to ACI 318-11 [57] and to fit the capacity of the available testing facility in the Structural Engineering Laboratory of the University of Wollongong, Australia. According to ACI 318-11 [57], the concrete columns are defined as vertical members, which are used primarily to carry compressive axial load, with the ratio of height-to-least lateral dimension greater than 3. In this study, the ratio of the height-to-least lateral dimension of the tested specimens was 5.3. The influence of the size of column specimens was considered beyond the scope of the paper. 
117 The specimens of Group R were considered as reference RC specimens without any 118 wrapping. The specimens of Group P were partially wrapped with three layers of CFRP strips. The width and clear spacing of the CFRP strips were chosen to be the same as the width of the CFRP strip commonly used in the available experimental studies in the

121 literature $[23,31-34,58]$. The CFRP strips had the width and clear spacing of $60 \mathrm{~mm}$.

122 One CFRP strip was located at the mid-height of the specimens in order to avoid the failure at the mid-height, which was reported as the principal failure location for partially FRP wrapped RC columns [29, 32, 33, 40]. The specimens of Group F were fully wrapped with three layers of CFRP. The amount of CFRP used for specimens of Group F $\left(1,437,440 \mathrm{~mm}^{2}\right.$ per specimen (length $\mathrm{x}$ width $\mathrm{x}$ number of layer) was 1.6 times

127 of the amount of CFRP used for Group P specimens $\left(898,400 \mathrm{~mm}^{2}\right.$ per specimen 128 (length $\mathrm{x}$ width $\mathrm{x}$ number of layer)).

The notations of the specimens consist of two parts. The first part represents the name of the group and the second part represents the loading conditions of the tested specimens. In the first part of the specimen notation, the letters $\mathrm{R}, \mathrm{P}$, and $\mathrm{F}$ refer to the reference group, partial wrapping group and full wrapping group, respectively. The second part of the specimen notation is either the numbers $0,15,25$ or the letter $\mathrm{B}$ in which 0 refers to concentric axial load, 15 refers to $15 \mathrm{~mm}$ eccentric axial load, 25 refers to $25 \mathrm{~mm}$ eccentric axial load, and B refers to four-point bending. For example, Specimen P-25 is partially wrapped with three layers of CFRP and subjected to $25 \mathrm{~mm}$ 137 eccentric axial load. Specimen F-B is fully wrapped with three layers of CFRP and subjected to four-point bending. 
139 Each specimen was reinforced longitudinally with 4N12 bars (12 mm diameter 140 deformed steel bars) and transversely with R6 bars (6 mm diameter plain steel bars) at $14180 \mathrm{~mm}$ centre-to-centre spacing. The steel reinforcement of the specimens was chosen

142 based on the available studies to represent deficient columns $[3,5,20,21,26,32,33$, 143 41]. The concrete cover at the ends and at the sides of the specimens was $20 \mathrm{~mm}$. The 144 four corners of CFRP wrapped specimens were rounded to $20 \mathrm{~mm}$ radius over the 145 length of the specimen to obtain higher confinement effect of CFRP wrapping [51, 56].

146 The corner radius of $20 \mathrm{~mm}$ was chosen based on the recommendations in ACI 440.2R-

14717 [2] and FIB Bulletin 14 [56]. It is noted that the four corners of the reference 148 specimens were also rounded to $20 \mathrm{~mm}$ radius, as the ends of the reference specimens 149 were wrapped with CFRP to avoid premature failure due to stress concentration at the 150 ends during testing [20, 43]. The details of the geometry and the reinforcement of the 151 specimens are presented in Figure 1. Table 1 presents the configuration of tested 152 specimens.

\subsection{Specimen preparation}

154 All steel cages were manufactured at the Structural Engineering Laboratory of the 155 University of Wollongong, Australia. The steel cages were assembled from four N12 $156760 \mathrm{~mm}$ long longitudinal steel bars and ten R6 steel ties with $80 \mathrm{~mm}$ centre-to-centre 157 spacing. The square steel ties were manufactured by bending $520 \mathrm{~mm}$ long R6 plain steel bars. A $20 \mathrm{~mm}$ concrete cover at the four sides and at the two ends of the specimens were maintained by welding $20 \mathrm{~mm}$ long steel pins at the four sides of the

160 first and the last steel ties and at the bottom of the four longitudinal steel bars. 
161 The formwork of square RC specimens was made from Plywood. The plywood panels 162 were fixed by longitudinal and vertical timber bars to avoid bending and movement 163 during the casting of concrete. The rounded corners were generated by gluing styrofoam 164 at the corners of the formwork. Figure 2 shows the details of the steel cages and 165 formwork.

166 Ready-mix normal strength concrete was used for casting all specimens. The slump of 167 fresh concrete was $145 \mathrm{~mm}$. The measured compressive strength of concrete at $28^{\text {th }}$ day was $36 \mathrm{MPa}$. The specimens were cured by covering with wet hessian rugs and watering twice every working day. Plastic sheets were placed over the wet hessian rugs to maintain the moist condition during the curing process. The formwork was removed on 171 the 14th day after casting. However, the curing process was completed on the 28th day after casting. After the curing process, the specimens were kept in the room temperature without the wet hessian rugs until the day of testing.

174 The specimens were wrapped by the wet layup technique. The mixture of hardener and epoxy resin at a ratio of 1:5 was used as the adhesive. The wet layup technique was implemented in few steps. At first, the surface of the specimens was cleaned to make

177 surfaces smooth. Second, the concrete surface was coated with the adhesive by a paint 178 brush. Next, a continuous CFRP sheet was attached to the surface of the specimens in three layers. After the first CFRP layer was attached to the surface of the concrete specimens, a gear roller was used to eliminate the possible air voids between the concrete surface and the CFRP strips. Before attaching the second layer, the outer surface of the first layer was coated with the adhesive for an adequate bond between the layers. Then, the outer surface of the second layer was coated with the adhesive before 
installing the third layer. After attaching the third layer, a $100 \mathrm{~mm}$ long single overlapping zone between the starting and the finishing ends was maintained for each CFRP strip/sheet to prevent premature failure due to insufficient bonding $[3,5,20,21]$.

Finally, the outer surface of the third layer was coated with the adhesive for an adequate bond between the layers. The wrapped specimens were kept at room temperature for a minimum of 7 days to allow the epoxy to dry. Figure 3 shows the details of wrapping procedure.

\subsection{Test setup and instrumentation}

\subsubsection{Specimens subjected to concentric and eccentric axial loads}

193

194

The top and the bottom parts of all specimens tested as columns were wrapped with two additional layers of CFRP sheets to avoid premature failure caused by stressconcentration during testing. The top and bottom surfaces of the specimens were also capped with high strength plaster when the loading heads were attached to the columns for uniformly distributed axial loads. The loading heads consisted of two parts. The first part was the adaptor plate and the second part was the ball joint plate. The adaptor plate had a cross-section of $235 \mathrm{~mm} \times 235 \mathrm{~mm}$ and the thickness of $50 \mathrm{~mm}$. The ball joint plate was a $25 \mathrm{~mm}$ thick plate with a ball joint. The adaptor plates were attached to both ends of the specimens. The ball joints were connected to the adaptor plates through the grooves located along the length of the adaptor plates to generate the axial load eccentricity. The $15 \mathrm{~mm}$ and $25 \mathrm{~mm}$ eccentricities were generated when the ball joints were connected to the adaptor plates at the first and second grooves, respectively. Figure $4 \mathrm{c}$ shows the details of test setup for eccentric axial loads. For specimens 
subjected to concentric axial load, only the adaptor plate was used to apply the axial load.

Two linear variable differential transducers (LVDTs) were fixed at the two opposite corners of the bottom loading head for measuring the axial deformation of the tested specimens. The testing data was recorded at every 2 seconds via a data logger. Figure 4 presents the details of the test setup and instruments for specimens tested under concentric, eccentric axial loads and four-point bending.

The specimens were initially preloaded (force controlled) at the rate of $2 \mathrm{kN} / \mathrm{s}$ to approximately $100 \mathrm{kN}$, which was equivalent to about $10 \%$ of the anticipated ultimate axial load of the reference specimen. The specimens were then unloaded to $20 \mathrm{kN}$ at the same rate. The initial loading and unloading were carried out to prevent any movement in the specimens that might have occurred during the test. Afterwards, the specimens were tested until failure under a deformation controlled load at $0.3 \mathrm{~mm} / \mathrm{min}$. The test was stopped when the axial load sustained by the specimen, which was measured by the stroke of the machine, dropped by $25 \%$ of the ultimate axial load.

\subsubsection{Specimens subjected to four-point bending}

222 The flexural capacity of specimens was determined by four-point bending. The four223 point bending was exerted by using two rigs placed over and under the specimens. The 224 bottom rigs with a clear span of $700 \mathrm{~mm}$ were placed diagonally on the bottom loading 225 cell of the $5000 \mathrm{kN}$ Denison Compressive Testing Machine. After the specimen was placed on the bottom rigs, the top rig with a clear span of $233 \mathrm{~mm}$ was placed over the specimens. Accordingly, the beam specimens had a clear span of $700 \mathrm{~mm}$ with two shear spans of $233 \mathrm{~mm}$. During the test, the midspan deflection of the tested specimens 
was measured by a laser triangulation placed under the bottom rig. Figure $4 d$ shows the test setup for the specimens tested under four-point bending. The initial loading and unloading of the specimens tested under the four-point bending were similar to the initial loading and unloading for the specimens tested under concentric or eccentric axial loads. The test was stopped when either the applied flexural load dropped by $25 \%$ of the ultimate flexural load or the longitudinal steel bar fractured.

The dimension of the specimens tested as beams was kept the same as the dimension of the specimens tested as columns for uniformity and consistency. The behaviour of specimens tested as beams had low shear span to the depth ratio which might influence the pure bending moment $[20,21,43]$. The shear spans of Specimens R-B and P-B were additionally wrapped with three layers of CFRP to alleviate the influence of the shearinduced deflection at the midspan.

\subsection{Preliminary material testing}

The ready-mixed normal strength concrete with the maximum aggregate size of $10 \mathrm{~mm}$ was used for casting all the specimens. The compressive strength of concrete was determined according to AS 1012.9:2014 [59] by testing three standard concrete cylinders with $100 \mathrm{~mm}$ diameter and $200 \mathrm{~mm}$ height. The average 28-day compressive strength of concrete was $36 \mathrm{MPa}$.

247 The N12 deformed steel bars and R6 plain steel bars were used as longitudinal and 248 transverse reinforcement, respectively. Three $500 \mathrm{~mm}$ long samples from each steel reinforcement were tested to measure the tensile properties of reinforcement according to AS 1391-2007 [60]. The average yield tensile strengths of N12 deformed steel bars 
and R6 plain steel bars were 568 and $517 \mathrm{MPa}$, respectively. Table 2 reports the tensile properties of the longitudinal and transverse reinforcement.

The unidirectional CFRP with $0.167 \mathrm{~mm}$ nominal thickness and $300 \mathrm{~g} / \mathrm{m}^{2}$ unit weight was used as an external confining material. The tensile properties of CFRP were obtained by testing five coupons as recommended in ASTM D3039/D3039M-14 [61]. The coupons with the average width of $22.75 \mathrm{~mm}$ and the length of $250 \mathrm{~mm}$ were tested using $500 \mathrm{kN}$ Instron 8033 testing machine. The average tensile strength, corresponding tensile strain and elastic modulus of CFRP were $3726 \mathrm{MPa}, 1.55 \%$ and $240.43 \mathrm{GPa}$, respectively. Table 3 reports the tensile properties of CFRP.

\section{Experimental results and discussion}

\subsection{Failure modes of tested specimens}

The failure modes of column specimens tested under concentric axial load are shown in Figure 5. The failure of Specimen R-0 started with vertical cracks of the concrete cover at the mid-height and at the upper part of the specimen. Then, the spalling of the concrete cover occurred at the mid-height and at the upper part of Specimen R-0, which was followed by the buckling of steel bars at the mid-height.

The failure of Specimen P-0 started with the cracking of the concrete cover in the nonwrapped concrete cover above and below the mid-height of the specimen. The cracking of non-wrapped concrete cover initiated at the corner of the specimen and then spread in the whole circumference of the specimen. Meanwhile, the non-wrapped concrete cover near the two ends of Specimen P-0 was also initially cracked. Next, the small part (fibres) of CFRP strips above the mid-height of the specimen was ruptured, which was 
accompanied by an explosive sound and sudden drop of the axial load. The rupture of

274 CFRP fibres occurred at the corner of Specimen P-0. After the rupture of CFRP fibres,

275

276

277

278

279

280

281

282

283

284

285

286

287

288

the remaining part of CFRP fibres and other CFRP strips continued to carry the axial load. Later, the failure of Specimen P-0 occurred by the rupture of a CFRP strip, causing a loud sound and accompanied by the crushing of concrete, debonding of CFRP, and a large deformation of the specimen. The buckling of steel bars was observed at the non-wrapped location, which was below the ruptured CFRP strip.

For Specimen F-0, the failure was initiated by a snapping sound due to the internal cracking of concrete when the applied axial load reached the yield axial load. Stretching of the CFRP sheet occurred due to the cracking of concrete cover when the axial load approached the ultimate axial load. Then, Specimen F-0 experienced an explosive sound caused by the rupture of a portion of the CFRP sheet. The rupture of CFRP fibres resulted in a sudden drop in the axial load. Afterwards, Specimen F-0 failed by the rupture of about half of the CFRP sheet located above the mid-height of the specimen, causing a very loud sound. The explosive failure indicated the release of a large quantity of energy generated by the high confining pressure. It was observed by visual inspection that the crushing of concrete cover occurred in the whole circumstance of Specimen F0 . The cracking of concrete cover was much more severe at the corner of the specimen than in the flat area between the corners. The difference of the crushing of concrete covers indicated that the highest lateral confining pressure occurred at the corners and lowest lateral confining pressure occurred at the flat area between the corners.

The failure modes of column specimens tested under 15 and 25 concentric axial loads are shown in Figures 6 and Figure 7. The first sign of the failure of Specimens R-15 and 
R-25 was the vertical cracking of the concrete cover at the corner in the compression side of the specimens. The cracking of concrete cover occurred at the mid-height and below the mid-height, respectively, for Specimen R-15 and R-25. Then, the spalling of concrete cover and concrete core occurred along the compression side of the specimens, which was accompanied by transverse cracks in the tension side at the mid-height and below the mid-height of Specimens R-15 and R-25, respectively. The buckling of steel bars was observed in the compression side for Specimen R-15 and Specimen R-25.

The failure of Specimen P-15 and Specimen P-25 was initiated by the ripples of nonwrapped concrete cover above the mid-height of the specimen on the compression side. Afterwards, the outwards cracking of concrete cover was observed at the non-wrapped location along the height of the specimen on the compression side, which was followed not show any rupture of the CFRP strips at the failure. The buckling of steel bars at the non-wrapped location on the compression side was observed for both Specimens P-15 and P-25 when the concrete cover was removed.

The failure of Specimens F-15 and F-25 started with a snapping sound due to the cracking of concrete. Then, CFRP ripples appeared at the compression side due to the cracking of concrete cover. Afterwards, Specimens F-15 and F-25 experienced the transverse cracking in the compression side indicating the crushing of concrete cover, which was followed by the transverse cracks in the tension side. No crushing of concrete occurred on the tension side of both Specimens F-15 and F-25. beams because the clear span was smaller than four times the overall member depth $(h)$ 
and the position of concentrated loads was within a distance $2 h$ from the face of the support [62]. Accordingly, the failure modes of Specimens P-B, P-B and F-B should be characterized by shear failure. However, in order to investigate the flexural behaviour of the specimens, the additional wrapping within the shear spans of the beams was applied to prevent the shear failure. The failure of specimens tested under four-point bending was governed by the fracture of tensile steel bars, which was followed by crushing of compressive concrete and initiation of a wide vertical crack at the tension side. The failure modes of specimens tested under four-point bending are shown in Figure 8 . The failure of Specimen R-B was initiated by vertical cracking of concrete in the tension side, which was caused by flexural stresses. The vertical cracks initiated at the tension side of the midspan of the specimen and propagated to the compression side of the specimen. Afterwards, the vertical cracks occurred along two loading points of the specimen. The vertical crack at the midspan quickly widened when the applied load increased beyond the yield flexural load, which was followed by the crushing of concrete in the compression side. The failure of Specimen R-B occurred with the rupture of steel bar in the tension side causing an explosive sound and accompanied by a large deformation.

For Specimen P-B, the failure started with a vertical crack which occurred at the nonwrapped location near the midspan of the specimen. Afterwards, several vertical cracks occurred on the tension side along the length of the specimen at the non-wrapped locations. The specimen experienced the crushing of concrete on the compression side. The failure of Specimen P-B occurred by the rupture of steel bars on the tension side. For Specimen F-B, the failure was initiated with the vertical crack in the tension side at the midspan of the specimen. Then, the vertical cracks occurred along the length of the 
specimen and propagated to the compression side of the specimen. Similar to Specimen

344 P-B, Specimen F-B did not show any rupture of CFRP and failed with the rupture of 345 steel bars, causing an explosive sound.

\subsection{Load-deformation behaviour}

347 Table 4 reports the experimental results of the concentrically and eccentrically loaded 348 specimens. Table 5 reports the experimental results of the specimens subjected to four349 point bending.

350 The ductility of each specimen $(\lambda)$ was determined based on energy absorption as the ratio between the area under the axial load-axial deformation curve up to the ultimate axial deformation $\left(A_{1}\right)$ and the area under the curve up to the yield axial deformation $\left(A_{2}\right)[32,52]$ as:

$$
\lambda=\frac{A_{1}}{A_{2}}
$$

354 The ultimate axial deformation was defined as the deformation corresponding to 0.85

355 times the ultimate axial load in the descending part of the axial load-axial deformation 356 curve [63]. The yield axial deformation was the deformation at the yield axial load. The 357 yield load corresponds to the intersection point between a horizontal line drawn from the first peak axial load and the straight line passing through the origin and the point representing $75 \%$ of the first peak axial load [64]. For four-point bending, a similar method was applied to define the ductility; however, the flexural load-midspan

361 deflection curve was used instead of the axial load-axial deformation curve.

\subsubsection{Behaviour of concentrically loaded specimens}


363 Figure 9 shows the axial load-axial deformation behaviour of concentrically loaded 364 specimens. The linear ascending part of the axial load-axial deformation response of Specimens R-0, P-0 and F-0 showed similar patterns indicating identical stiffness of the specimens. This similar linear ascending part represented the behaviour of non-wrapped concrete. However, the post-peak axial load-axial deformation behaviours of Specimens R-0, P-0 and F-0 were different due to different confinement effect for different wrapping schemes (non-wrapping, partial wrapping, and full wrapping) when concrete cracked and CFRP wrapping activated. It was reported in previous studies that the FRP was effectively activated when concrete cracked, which occurred when the compressive stress reached approximately $87 \%$ [65] or about $90 \%$ [15] of the non-wrapped concrete strength. The axial load of Specimen R-0 quickly decreased to failure load due to the complete spalling of concrete cover after reaching the ultimate axial load. Unlike Specimen R-0, the axial load-axial deformation responses of Specimens P-0 and F-0 showed nearly a bi-linear axial load-axial deformation response. The axial load-axial deformation behaviour of Specimen P-0 exhibited a post-peak descending response in axial load-axial deformation behaviour of Specimen F-0 exhibited a post-peak ascending response in which the axial load significantly increased to reach the ultimate axial load after the yield axial load.

The axial load of Specimen P-0 slightly decreased by $6.6 \%$ after reaching the ultimate axial load starting from $1114.2 \mathrm{kN}$ to $1044.8 \mathrm{kN}$ at the rupture of CFRP fibres and failed at $893.2 \mathrm{kN}$ with the rupture of the whole width of CFRP strip. The slight decrease in the axial load of Specimen P-0 was due to the cracking and the spalling of 
strips by generating lateral confining pressure delayed the cracking of concrete cover and resulted in the higher ultimate axial load of Specimen P-0 compared to Specimen R-0. The lateral confining pressure generated by CFRP strips also prevented the sudden drop of axial load after reaching the ultimate axial load. For Specimen F-0, after the axial yield load, the axial load significantly increased to the ultimate axial load of $1614.5 \mathrm{kN}$. The significant increase of axial load of Specimen F-0 was due to the full wrapping, which provided sufficient lateral confining pressure along the height of specimen to alleviate and prevent the dilation of concrete core due to Poisson's effect. Hence, the failure of Specimen F-0 was due to the rupture of CFRP.

As can be seen in Figure 9 and Table 4, partial and full wrapping resulted in an increase in the axial load of square RC specimens. Specimen F-0 obtained the highest ultimate axial load (1614.5 kN), followed by Specimen P-0 (1114.2 kN) and R-0 (993.5 kN). The ultimate axial load of Specimen F-0 was $62.5 \%$ higher than the ultimate axial load of Specimen R-0. The ultimate axial load of Specimen P-0 was $12.1 \%$ higher than the ultimate axial load of Specimen R-0. The ultimate axial load of Specimen P-0 was 44.9\% lower than the ultimate axial load of Specimen F-0. The lower ultimate axial load of Specimen P-0 compared to Specimen F-0 was due to the cracking and spalling of non-wrapped concrete cover.

In terms of ductility, both partial and full wrapping resulted in a significant increase in the ductility of square RC specimens. The ductility of Specimen F-0 was $919.4 \%$ higher than the ductility of Specimen R-0. The ductility of Specimen P-0 was $400 \%$ higher than the ductility of Specimen R-0. The significant increase in ductility was due to the confinement effect of full and partial wrapping. The confinement effect resulted in the 
significant increase of the post-peak ultimate axial load of Specimen F-0 and slight decrease of the post-peak ultimate axial load of Specimen P-0. The ductility of Specimen P-0 was $103.8 \%$ lower than the ductility of Specimen F-0. This was attributed to the fact that full wrapping prevented the failure of concrete cover, which occurred in Specimen P-0, and resulted in an ascending post-peak axial load of Specimen F-0.

Figure 10 presents the axial load-axial deformation and axial load-lateral deformation responses of specimens subjected to $15 \mathrm{~mm}$ eccentric axial load. Similar to the specimens tested under concentric axial load, the linear ascending part of axial loadaxial deformation responses of Specimens R-15, P-15 and F-15 were similar indicating the identical stiffness of the specimens. In other words, CFRP strips and CFRP sheets did not have significant effect on the behaviour of tested specimens before cracking of concrete. The post-peak axial load-axial deformation behaviours of Specimens R-15, P15 and F-15 showed a descending response. The axial load of Specimen R-15 dropped immediately after the ultimate axial load. However, the axial load of Specimens F-15 and P-15 steadily decreased after the peak axial load. higher than the ultimate axial load of Specimens R-15 $(731.8 \mathrm{kN})$. The ultimate axial load of Specimen P-15 $(802.3 \mathrm{kN})$ was $9.6 \%$ higher than the ultimate axial load of Specimen R-15. The lower ultimate axial load of Specimen P-15 compared to Specimen F-15 was due to the cracking of non-wrapped concrete cover at the compression side. The ductility of Specimen P-15 was $204.2 \%$ higher than the ductility of Specimens R15, which was attributed to the contribution of confinement effect of CFRP strips. The confinement generated by CFRP strips lead to the progressive reduction of post-peak 
axial load of Specimen P-15. Specimen P-15 obtained $89.8 \%$ lower ductility than

434 Specimen F-15 because full wrapping prevented severe cracking of non-wrapped concrete in the compression side and resulted in a gradual decrease of post-peak axial load of Specimen F-15.

The axial load-axial deformation response and the axial load-lateral deformation response of specimens tested under $25 \mathrm{~mm}$ eccentric axial load are shown in Figure 11. The post-peak axial load-axial deformation behaviour of Specimens R-25, P-25 and F25 showed descending responses. For Specimen R-25, the axial load quickly decreased to the failure load after the ultimate axial load. The axial load of Specimen F-25 decreased slightly after the ultimate axial load, which was similar to the decrease of the axial load of Specimen F-15 after the ultimate axial load. For Specimen P-25, unlike Specimen P-15 in which the axial load progressively decreased to the failure load after reaching the ultimate axial load, the axial load of Specimen P-25 immediately reduced to the failure load after the ultimate axial load. The significant decrease of the axial load of Specimen P-25 after the ultimate axial load was attributed to the severe cracking of non-wrapped concrete cover in the compression side. The difference of the post-peak responses of Specimens F-25 and P-25 was due to the cracking of non-wrapped concrete in the compression side of Specimen P-25.

Specimen F-25 sustained the highest ultimate axial load of $876.6 \mathrm{kN}$, which was $39.1 \%$ higher than the ultimate axial load of Specimen R-25 $(630.2 \mathrm{kN})$. The ultimate axial load of Specimen P-25 was 8.6\% higher than the ultimate axial load of Specimen R-25.

454 The increase in the axial load of Specimen P-25 compared to Specimen R-25 was not highly significant, as the early cracking and spalling of non-wrapped concrete cover 
occurred in the compression side. The higher ultimate axial load of Specimen F-25 compared to Specimens P-25 was attributed to the fact that the concrete cover of the compression side of Specimen F-25 was confined by CFRP sheets and sustained the eccentric axial load until failure. Specimen F-25 achieved the highest ductility, which was $317.3 \%$ higher than the ductility of Specimens R-25. The ductility of Specimen P25 was $101 \%$ higher than the ductility of Specimen R-25 and $107.6 \%$ lower than the ductility of Specimen F-25. The higher ductility of Specimen F-25 compared to Specimen P-25 was attributed to the gradual decrease of post-peak axial load.

\subsubsection{Behaviour of specimens tested under four-point bending}

Flexural load versus midspan deflections of beam specimens tested under four-point bending is shown in Figure 12. Table 6 reports the experimental results of specimens tested under four-point bending. The linear ascending parts of the flexural load-midspan deflection behaviours of Specimens R-B, P-B and F-B were similar, indicating identical stiffness of the specimens. The post-peak flexural load-midspan deflection behaviours of Specimens P-B and F-B showed an ascending response while the post-peak flexural load-midspan deflection behaviour of Specimen R-B showed a descending response. The post-peak ascending flexural load-midspan deflection behaviour of Specimens P-B and F-B could be attributed to the confinement effect of CFRP on the compressive concrete of the CFRP wrapped beam specimens after the yielding of tensile longitudinal steel bars. The higher ultimate flexural load and the post-peak ascending flexural loadmidspan deflection behaviour of the beam specimens externally wrapped with CFRP were also observed in Hadi and Widiarsa [5], Hadi et al. [20], Pham et al. [21]. The flexural load-midspan deflection behaviours of Specimens R-B, P-B and F-B indicated the yielding of steel reinforcements before the crushing of concrete. The flexural load- 
midspan deflection behaviours of Specimens R-B, P-B and F-B ended with the rupture of steel reinforcements.

482

483

484

485

Specimen F-B sustained 50.1\% higher ultimate flexural load and $469.7 \%$ higher midspan deflection at the ultimate flexural load than Specimen R-B. Specimen P-B carried $23.6 \%$ higher ultimate flexural load and $300 \%$ higher midspan deflection at the ultimate axial load than Specimen R-B. The ultimate flexural load and mid-span deflection at the ultimate flexural load of Specimen P-B were $21.4 \%$ and $42.3 \%$, respectively lower than the ultimate flexural load and mid-span deflection at the ultimate flexural load of Specimen F-B. The ductility of Specimen R-B and Specimen P-B were almost the same and lower than the ductility of Specimen F-B by $20.2 \%$ and $18 \%$, respectively.

\subsection{Effect of axial load eccentricity}

Figure 13 shows the effect of axial load eccentricity on the ultimate axial load and the ductility of specimens. It can be observed that the increase in the axial load eccentricity resulted in the decrease in the strength and ductility of the specimens. The decrease of the ultimate axial load corresponding to the increase of the axial load eccentricity was due to the reduction of compression area of the concrete confined by CFRP. However, for the partially wrapped specimens, the rate of decrease of the ultimate axial load and ductility with the increase of the axial load eccentricity is lower than those of fully wrapped specimens. It was observed that, for partially and fully wrapped specimens, the rate of decrease of the ultimate axial load and ductility when the eccentricity increased from 0 to $15 \mathrm{~mm}$ was higher than the rate of decrease of the ultimate axial load and ductility when the axial load eccentricity increased from $15 \mathrm{~mm}$ to $25 \mathrm{~mm}$. 
503 It can be seen in Figure 13 that when the axial load eccentricity increased from 0 to 15

$504 \mathrm{~mm}$, the ultimate axial load of fully and partially wrapped specimens reduced by $37.7 \%$

505 and $28 \%$, respectively. The ultimate axial load reduced by $12.9 \%$ and $14.4 \%$,

506 respectively, for fully and partially wrapped specimens when the axial load eccentricity

507 increased from $15 \mathrm{~mm}$ to $25 \mathrm{~mm}$. Similar to the trend of decrease of the ultimate axial

508 load, the rate of decrease of the ductility of fully and partially wrapped specimens when

509 the eccentricity increased from $0 \mathrm{~mm}$ to $15 \mathrm{~mm}$ was higher than that when the axial load

510 eccentricity increased from 0 to $15 \mathrm{~mm}$. The ductility of fully and partially wrapped

511 specimens reduced by $54.9 \%$ and $51.5 \%$, respectively, when the axial load eccentricity

512 increased from 0 to $15 \mathrm{~mm}$ and reduced by $28.2 \%$ and $24.1 \%$, respectively, when the

513 axial load eccentricity increased from 15 to $25 \mathrm{~mm}$.

\section{4. Axial load and bending moment interaction diagrams}

515 The experimental axial load-bending moment (P-M) interaction diagrams of tested 516 specimens were plotted in Figure 14. The P-M interaction diagrams were drawn based 517 on four points. The first point presents the pure axial load of column specimen tested 518 under concentric axial load. The second and third points present the axial load and 519 corresponding bending moment of column specimen tested under $15 \mathrm{~mm}$ and $25 \mathrm{~mm}$ 520 eccentric axial load, respectively. The fourth point presents the bending moment of 521 beam specimen tested under four-point bending.

522 The bending moment $\left(M_{u}\right)$ of the specimens tested under eccentric axial loads and four-

523 point bending were calculated using Eq. (2) and Eq. (3), respectively.

$$
M=P_{u}(e+\delta)
$$




$$
M=\frac{1}{2} P_{u} L
$$

524 where $e$ is the axial load eccentricity, $\delta$ is the lateral deformation at the mid-height of 525 the column corresponding to the ultimate axial load, $P_{u}$ is the ultimate load, and $L$ is the 526 span length between two supports of the beam specimens. In this study, $L$ is taken as $527233 \mathrm{~mm}$.

528 The experimental ultimate axial load and bending moment of specimens are reported in 529 Table 6. As can be seen in Figure 14, fully CFRP wrapped specimens had the highest axial load and maximum bending moment followed by the partially CFRP wrapped specimens and non-wrapped specimens. Under $15 \mathrm{~mm}$ eccentric axial load, the bending moments of Specimen F-15 was $79.8 \%$ higher than the bending moment of Specimen R-15. The bending moment of Specimen P-15 was $14.3 \%$ higher than the bending moment of Specimen R-15 and 57.2\% lower than that of Specimen F-15. Under $25 \mathrm{~mm}$ eccentric axial load, the bending moment of Specimen F-25 increased by $111.2 \%$ compared to the bending moment of Specimen R-25. The bending moment of Specimen P-25 was 52.3\% higher than the bending moment of Specimen R-25 and 38.7\% lower than the bending moment of Specimen F-25.

539 For four-point bending, the bending moment of Specimen F-B was $72.6 \%$ higher than 540 the bending moment of Specimen R-B. The bending moment of Specimen P-B was $5412.1 \%$ higher the bending moment of Specimen R-B and $21.4 \%$ lower than that of 542 Specimen F-B.

543 The higher ultimate axial load and bending moment capacity of specimens of Group $\mathrm{P}$ 544 compared to those of specimens of Group $\mathrm{R}$ were attributed to the increase of the 
ultimate axial load and lateral deformation at the ultimate axial load. The increase in the ultimate axial load and lateral deformation at the ultimate axial load of partially wrapped square $\mathrm{RC}$ specimens was due to the lateral confining pressure generated by the CFRP strips. The axial load and bending moment capacity of the specimens of

549 Group F were significantly higher than the axial load and bending moment capacity of the specimens of Group P. This was because of the fact that the full wrapping of specimens resulted in a significant increase of the axial load and lateral deformation compared to the partial wrapping of specimens, albeit with the use of 1.6 times of the CFRP used for Group P specimens.

\section{Conclusions}

A total of twelve square RC specimens were tested to examine the behaviour of square RC specimens for different wrapping schemes (non-wrapping, partial wrapping and full wrapping) under different loading conditions (concentric axial load, eccentric axial load and four-point bending). Based on the experimental results, the following conclusions are drawn:

1. Partial wrapping improved the performance of square RC specimens under different axial load eccentricities. The increase in the strength was $12.1 \%, 9.6 \%$, and $8.6 \%$, respectively, and the increase in the ductility was $400 \%, 204.2 \%$ and $101 \%$, respectively, under concentric axial load, $15 \mathrm{~mm}$ and $25 \mathrm{~mm}$ eccentric axial loads. Under four-point bending, for partial wrapping, the ultimate flexural load was increased by $49.8 \%$ and the ductility increased by $2.6 \%$.

2. Full wrapping of square RC specimens led to a significant increase in the axial load and ductility under different axial load eccentricities. The ultimate axial load was 
increased by $72.6 \%, 29.3 \%$, and $31.1 \%$, respectively, and the ductility was increased by $919.4 \%, 477.3 \%$ and $317.3 \%$, respectively, under concentric axial load, $15 \mathrm{~mm}$ and $25 \mathrm{~mm}$ eccentric axial loads. Under four-point bending, for fully wrapped specimens, the ultimate flexural load was increased by $50.1 \%$ and the ductility was

3. The increase in the strength and ductility of fully wrapped square column specimens was higher than the increase in the strength and ductility of partially wrapped square

4. Fully wrapped square RC specimens exhibited the largest reduction in the strength and ductility when the axial load eccentricity increased from 0 to $25 \mathrm{~mm}$, followed by the reduction of the strength and ductility of partially wrapped specimens. The ultimate axial strength of fully and partially wrapped square RC specimens reduced by $37.7 \%$ and $28 \%$, respectively, when the axial load eccentricity increased from 0 to $15 \mathrm{~mm}$ and reduced by $45.7 \%$ and $38.5 \%$ when the eccentricity increased from 0 to $25 \mathrm{~mm}$. The ductility of fully and partially wrapped square RC specimens was reduced by $54.9 \%$ and $51.5 \%$, respectively, when the axial load eccentricity 
increased from 0 to $15 \mathrm{~mm}$ and reduced by $66.8 \%$ and $65.2 \%$ when eccentricity increased from 0 to $25 \mathrm{~mm}$.

5. The axial load-bending moment capacity of partially wrapped specimens was higher than the axial load-bending moment capacity of non-wrapped specimens. The axial load-bending moment capacity of fully wrapped specimens was higher than the axial load-bending moment capacity of partially wrapped specimens.

\section{Acknowledgements}

The authors would like to thank Messrs Richie Mclean, Fernando Escribano, Richard Gasser, Duncan Best and Alan Grant of the Structural Engineering Laboratory at the University of Wollongong, Australia for their technical support. The contribution of the University of Wollongong, Australia for supporting the experimental program is highly appreciated. The first author would like to express his gratitude to the Australian Government for funding of his Ph.D studies.

\section{References}

[1] J.G. Teng, L. Lam, Compressive behavior of carbon fiber reinforced polymerconfined concrete in elliptical columns, J. Struct. Eng. 128(12) (2002) 1535-1543.

[2] ACI (American Concrete Institute), Guide for the Design and Construction of Externally Bonded FRP Systems for Strengthening Concrete Structures, ACI 440.2R17, Farmington Hills, MI, USA, 2017.

[3] M.N.S. Hadi, M.T. Jameel, M.N. Sheikh, Behavior of Circularized Hollow RC Columns under Different Loading Conditions, J. Compos. Constr. 21(5) (2017) 04017025.

[4] J.G. Teng, J.F. Chen, S.T. Smith, L. Lam, FRP-strengthened RC structures, John Wiley \& Sons, LTD, UK, 2002. 
616 [5] M.N.S. Hadi, I.B.R. Widiarsa, Axial and flexural performance of square RC

617 columns wrapped with CFRP under eccentric loading, J. Compos. Constr. 16(6) (2012)

$618 \quad 640-649$.

619 [6] H. Erdogan, P. Zohrevand, A. Mirmiran, Effectiveness of externally applied CFRP

620 stirrups for rehabilitation of slab-column connections, J. Compos. Constr. 17(6) (2013)

62104013008.

622 [7] H.A. Toutanji, Stress-strain characteristics of concrete columns externally confined 623 with advanced fiber composite sheets, ACI Mater. J. 96(3) (1999) 397-404.

624 [8] L. Lam, J.G. Teng, Design-oriented stress-strain model for FRP-confined concrete, 625 Constr. Build. Mater. 17(6-7) (2003a) 471-489.

626 [9] M.N.S. Hadi, Behaviour of FRP wrapped normal strength concrete columns unde 627 eccentric loading, Compos. Struct. 72(4) (2006) 503-511.

628 [10] V. Yazici, M.N.S. Hadi, Axial load-bending moment diagrams of carbon FRP

629 wrapped hollow core reinforced concrete columns, J. Compos. Constr. 13(4) (2009) $630 \quad 262-268$.

631

632

[11] Y. Wu, Y. Zhou, Unified Strength Model Based on Hoek-Brown Failure Criterion 633 for Circular and Square Concrete Columns Confined by FRP, J. Compos. Constr. 14(2) (2010) 175-184.

634

[12] B. Csuka, L.P. Kollár, Analysis of FRP confined columns under eccentric loading, 635 Compos. Struct. 94(3) (2012) 1106-1116.

636 [13] K.H. Tan, Strength enhancement of rectangular reinforced concrete columns using 637 fiber-reinforced polymer, J. Compos. Constr. 6(3) (2002) 175-183.

638 [14] T. Jiang, J.G. Teng, Behavior and design of slender FRP-confined circular RC 639 columns, J. Compos. Constr. 17(4) (2013) 443-453.

640 [15] J.G. Teng, L. Lam, Behavior and modeling of fiber reinforced polymer-confined 641 concrete, J. Struct. Eng. 130(11) (2004) 1713-1723. 
642 [16] J.G. Teng, T. Jiang, L. Lam, Y.Z. Luo, Refinement of a design-oriented stress-

643 strain model for FRP-confined concrete, J. Compos. Constr. 13(4) (2009) 269-278.

644 [17] G. Lin, T. Yu, J.G. Teng, Design-Oriented Stress-Strain Model for Concrete under

645 Combined FRP-Steel Confinement, J. Compos. Constr. 20(4) (2016).

646 [18] M.N.S. Hadi, J. Li, External reinforcement of high strength concrete columns,

647 Compos. Struct. 65(3-4) (2004) 279-287.

648 [19] M.N.S. Hadi, Comparative study of eccentrically loaded FRP wrapped columns, 649 Compos. Struct. 74(2) (2006) 127-135.

650 [20] M.N.S. Hadi, T.M. Pham, X. Lei, New method of strengthening reinforced 651 concrete square columns by circularizing and wrapping with fiber-reinforced polymer or 652 steel straps, J. Compos. Constr. 17(2) (2013) 229-238.

653 [21] T.M. Pham, L.V. Doan, M.N.S. Hadi, Strengthening square reinforced concrete 654 columns by circularisation and FRP confinement, Constr. Build. Mater. 49 (2013) 490655499.

656 [22] L. Lam, J.G. Teng, Design-oriented stress-strain model for FRP-confined concrete 657 in rectangular columns, J. Reinf. Plast. Compost. 22(13) (2003b) 1149-1186.

658 [23] J.A.O. Barros, D.R.S.M. Ferreira, Assessing the Efficiency of CFRP Discrete 659 Confinement Systems for Concrete Cylinders, J. Compos. Constr. 12(2) (2008) 134660148

661 [24] T.W. Park, U.J. Na, L. Chung, M.Q. Feng, Compressive behavior of concrete 662 cylinders confined by narrow strips of CFRP with spacing, Compos. Part B: Eng. 39(7663 8) (2008) 1093-1103.

664 [25] T.M. Pham, M.N.S. Hadi, J. Youssef, Optimized FRP Wrapping Schemes for 665 Circular Concrete Columns under Axial Compression, J. Compos. Constr. 19(6) (2015) $666 \quad 04015015$. 
667 [26] G. Campione, Influence of FRP wrapping techniques on the compressive behavior 668 of concrete prisms, Cem. Concr. Compos. 28(5) (2006) 497-505.

669 [27] G. Campione, L. La Mendola, A. Monaco, A. Valenza, V. Fiore, Behavior in 670 compression of concrete cylinders externally wrapped with basalt fibers, Compos. Part 671 B: Eng. 69 (2014) 507-586.

672 [28] S. Matthys, H. Toutanji, K. Audenaert, L. Taerwe, Axial load behavior of large673 scale columns confined with fiber-reinforced polymer composites, ACI Struct. J. 102(2) 674 (2005) 258-267.

675 [29] O.A. Hodhod, W. Hassan, M.S. Hilal, H. Bahnasawy, Strength and ductility of 676 biaxially loaded high strength RC short square columns wrapped with GFRP jackets, 677 Struct. Eng. Mech. 20(6) (2005) 727-745.

678 [30] T.E. Maaddawy, Strengthening of Eccentrically Loaded Reinforced Concrete 679 Columns with Fiber-Reinforced Polymer Wrapping System: Experimental Investigation 680 and Analytical Modeling, J. Compos. Constr. 13(1) (2009) 13-24.

[31] W.M. Hassan, O.A. Hodhod, M.S.M. Hilal, H.H. Bahnsawy, Behavior of high 682 strength concrete columns subjected to small biaxial eccentricity and strengthened by FRP laminates, ACI Spec. Public. (2012) 111-132.

[32] A. Saljoughian, D. Mostofinejad, Axial-flexural interaction in square RC columns 685 confined by intermittent CFRP wraps, Compos. Part B: Eng. 89 (2016a) 85-95.

686 [33] A. Saljoughian, D. Mostofinejad, Corner Strip-Batten Technique for FRP687 Confinement of Square RC Columns under Eccentric Loading, J. Compos. Constr. $688 \quad 20(3)(2016 b) 04015077$.

689 [34] F. Colomb, H. Tobbi, E. Ferrier, P. Hamelin, Seismic retrofit of reinforced concrete 690 short columns by CFRP materials, Compos. Struct. 82(4) (2008) 475-487.

691 [35] H. Saadatmanesh, M.R. Ehsani, M.W. Li, Strength and ductility of concrete 692 columns externally reinforced with fiber composite straps, ACI Struct. J. 91(4) (1994) 693 434-447. 
694 [36] G.G. Triantafyllou, T.C. Rousakis, A.I. Karabinis, Axially loaded reinforced 695 concrete columns with a square section partially confined by light GFRP straps, J. 696 Compos. Constr. 19(1) (2015) 04014035.

697 [37] J.A.O. Barros, D.R.S.M. Ferreira, R.K. Varma, CFRP-confined reinforced concrete 698 elements subjected to cyclic compressive loading, ACI Spec. Public. (2007) 85-104.

699 [38] J.J. Zeng, Y.C. Guo, W.Y. Gao, J.Z. Li, J.H. Xie, Behavior of partially and fully 700 FRP-confined circularized square columns under axial compression, Constr. Build. 701 Mater. 152 (2017) 319-332.

702 [39] W.M. Hassan, O.A. Hodhod, M.S. Hilal, H.H. Bahnasaway, Behavior of 703 eccentrically loaded high strength concrete columns jacketed with FRP laminates, 704 Constr. Build. Mater. 138 (2017) 508-527.

705 [40] D. Mostofinejad, E. Ilia, Confining of square RC columns with FRP sheets using 706 corner strip-batten technique, Constr. Build. Mater. 70 (2014) 269-278.

707 [41] T.E. Maaddawy, Behavior of corrosion-damaged RC columns wrapped with FRP 708 under combined flexural and axial loading, Cem. Concr. Compos. 30(6) (2008) 524709 534.

710 [42] R.F. Warner, S.J. Foster, A.E. Kilpatrick, Reinforced Concrete Basics: Analysis and design of reinforced concrete structures, Pearson Education Australia, Sydney NSW 2086, Australia, 2007. [43] M.N.S. Hadi, J. Youssef, Experimental investigation of GFRP-reinforced and 714 GFRP-encased square concrete specimens under axial and eccentric load, and four-point 715 bending test, J. Compos. Constr. 20(5) (2016) 04016020.

716 [44] J. Li, M.N.S. Hadi, Behaviour of externally confined high-strength concrete 717 columns under eccentric loading, Compos. Struct. 62(2) (2003) 145-153.

718 [45] M.N.S. Hadi, Behaviour of FRP strengthened concrete columns under eccentric 719 compression loading, Compos. Struct. 77(1) (2007) 92-96. 
[46] L. Bisby, M. Ranger, Axial-flexural interaction in circular FRP-confined reinforced concrete columns, Constr. Build. Mater. 24(9) (2010) 1672-1681.

[47] A. Mirmiran, H. Shahawy, M. Samaan, H.E. Echary, J.C. Mastrapa, O. Pico, Effect of Column Parameters on FRP-Confined Concrete, J. Compos. Constr. 2(4) (1998) 175185.

[48] S. Pessiki, K.A. Harries, K.J. T., R. Sause, J.M. Ricles, Axial Behavior of Reinforced Concrete Columns Confined with FRP Jackets, J. Compos. Constr. 5(4) (2001) 237-245.

[49] J.H.J. Kim, S.T. Yi, S.H. Lee, S.K. Park, J.K. Kim, Compressive behaviour of CFS strengthened concrete specimens with various cross-sectional shapes and laminations, Mag. Concr. Res. 55(5) (2003) 407-418.

[50] X. Yang, J. Wei, A. Nanni, L.R. Dharani, Shape Effect on the Performance of Carbon Fiber Reinforced Polymer Wraps, J. Compos. Constr. 8(5) (2004) 444-451.

[51] L.M. Wang, Y.F. Wu, Effect of corner radius on the performance of CFRPconfined square concrete columns: Test, Eng. Struct. 30(2) (2008) 493-505.

[52] T.E. Maaddawy, M.E. Sayed, B. Abdel-Magid, The effects of cross-sectional shape and loading condition on performance of reinforced concrete members confined with Carbon Fiber-Reinforced Polymers, Mater. Des. 31(5) (2010) 2330-2341.

[53] M.H. Harajli, Axial stress-strain relationship for FRP confined circular and rectangular concrete columns, Cem. Concr. Compos. 28(10) (2006) 938-948.

[54] M.T. Jameel, M.N. Sheikh, M.N.S. Hadi, Behaviour of circularized and FRP wrapped hollow concrete specimens under axial compressive load, Compos. Struct. 171 (2017) 538-548.

[55] P. Rochette, P. Labossière, Axial testing of rectangular column models confined with composites, J. Compos. Constr. 4(3) (2000) 129-136. 
[56] FIB (The International Federation for Structure Concrete), Externally bonded FRP

746 reinforcement for RC structures, FIB Bulletin 14, Case Postale 88, CH-1015 Lausanne,

747 Switzerland, 2001.

748 [57] ACI (American Concrete Institute), Building Code Requirements for Structural 749 Concrete, ACI 318-11, 38800 Country Club Drive, Farmington Hills, MI 48331, USA, 7502011.

751 [58] D. Mostofinejad, N. Moshiri, N. Mortazavi, Effect of corner radius and aspect ratio 752 on compressive behavior of rectangular concrete columns confined with CFRP, Mater. 753 Struct. 48(1-2) (2015) 107-122.

754 [59] AS (Australian Standard), Methods of testing concrete: Method 9: Compressive 755 strength tests-Concrete, mortar and grout specimens, Australian Standard AS 13912007, Standards Australia Limited, GPO Box 476, Sydney, NSW 2001, Australia, 2014. [60] AS (Australian Standard), Metallic materials-Tensile testing at ambient temperature, AS 1391-2007, Standards Australia Limited, GPO Box 476, Sydney, NSW 2001, Australia, 2007.

760 [61] ASTM (American Society for Testing and Materials), Standard Test Method for Tensile Properties of Polymer Matrix Composite Materials, ASTM D3039/D3039M-14, ASTM International, 100 Barr Harbor Drive, PO Box C700, West Conshohocken, USA, 2008.

764 [62] ACI (American Concrete Institute), Building Code Requirements for Structural 765 Concrete, ACI 318M-14, 38800 Country Club Drive, Farmington Hills, MI 48331, 766 USA, 2014.

767 [63] S. Pessiki, A. Pieroni, Axial load behavior of large-scale spirally-reinforced high768 strength concrete columns, ACI Struct. J. 94(3) (1997) 304-314. [64] S.J. Foster, M.M. Attard, Experimental tests on eccentrically loaded high-strength concrete columns, ACI Struct. J. 94(3) (1997) 295-303. 
771 [65] A.Z. Fam, S.H. Rizkalla, Confinement model for axially loaded concrete confined

772 by circular fiber-reinforced polymer tubes, ACI Struct. J. 98(4) (2001) 451-461. 
Table 1: Configuration of tested specimens

\begin{tabular}{|c|c|c|c|c|c|c|c|}
\hline Group & Specimen & $\begin{array}{l}\text { Longitudinal } \\
\text { reinforcement }\end{array}$ & $\begin{array}{l}\text { Transverse } \\
\text { reinforcement }\end{array}$ & $\begin{array}{l}\text { Type of } \\
\text { wrapping }\end{array}$ & $\begin{array}{c}\text { Clear spacing of } \\
\text { CFRP strips } \\
(\mathrm{mm})\end{array}$ & $\begin{array}{l}\text { Amount of } \\
\text { used CFRP* } \\
\quad\left(\mathrm{mm}^{2}\right)\end{array}$ & $\begin{array}{c}\text { Eccentricity } \\
(\mathrm{mm})\end{array}$ \\
\hline \multirow{4}{*}{$\mathrm{R}$} & $\mathrm{R}-0$ & \multirow{4}{*}{$4 \mathrm{~N} 12$} & \multirow{4}{*}{ R6@80 } & \multirow{4}{*}{ None } & \multirow{4}{*}{-} & \multirow{4}{*}{0} & 0 \\
\hline & $\mathrm{R}-15$ & & & & & & 15 \\
\hline & R-25 & & & & & & 25 \\
\hline & R-B & & & & & & Bending \\
\hline \multirow{4}{*}{$\mathrm{P}$} & P-0 & \multirow{4}{*}{$4 \mathrm{~N} 12$} & \multirow{4}{*}{ R6@80 } & \multirow{4}{*}{$\begin{array}{c}\text { Partial } \\
(\text { width = } \\
60 \mathrm{~mm})\end{array}$} & \multirow{4}{*}{60} & \multirow{4}{*}{898,400} & 0 \\
\hline & P-15 & & & & & & 15 \\
\hline & P-25 & & & & & & 25 \\
\hline & P-B & & & & & & Bending \\
\hline \multirow{4}{*}{$\mathrm{F}$} & F-0 & \multirow{4}{*}{$4 \mathrm{~N} 12$} & \multirow{4}{*}{ R6@80 } & \multirow{4}{*}{ Full } & \multirow{4}{*}{0} & \multirow{4}{*}{$1,437,440$} & 0 \\
\hline & F-15 & & & & & & 15 \\
\hline & $\mathrm{F}-25$ & & & & & & 25 \\
\hline & F-B & & & & & & Bending \\
\hline
\end{tabular}

* Amount of CFRP used per specimen = (length) $\mathrm{x}($ width $) \mathrm{x}$ (number of layers) 
776 Table 2: Tensile properties of the steel bars

\begin{tabular}{cccccc}
\hline Bar & Reinforcement & $\begin{array}{c}\text { Diameter } \\
(\mathrm{mm})\end{array}$ & $\begin{array}{c}\text { Average tensile } \\
\text { yield strength } \\
f_{y}(\mathrm{MPa})^{\mathrm{a}}\end{array}$ & $\begin{array}{c}\text { Average tensile } \\
\text { yield strain }\end{array}$ & $\begin{array}{c}\text { Average tensile } \\
\varepsilon_{y}(\%)\end{array}$ \\
\hline N12 & Longitudinal & 12 & 568 & 0.327 & $E(\mathrm{GPa})^{\mathrm{b}}$ \\
\hline R6 & Transverse & 6 & 517 & 0.284 & 173 \\
\hline
\end{tabular}

$777 \quad{ }^{\mathrm{a}}$ Determined based on $0.2 \%$ offset method

$778{ }^{\mathrm{b}}$ Calculated as the slope of the linear elastic region of the stress-strain response 
Table 3: Mechanical properties of one layer of CFRP flat coupons

\begin{tabular}{ccccccc}
\hline Material & $\begin{array}{c}\text { Number } \\
\text { of layer }\end{array}$ & $\begin{array}{c}\text { Nominal } \\
\text { thickness } \\
(\mathrm{mm})\end{array}$ & $\begin{array}{c}\text { Width of } \\
\text { coupons } \\
(\mathrm{mm})\end{array}$ & $\begin{array}{c}\text { Ultimate tensile } \\
\text { strength } \\
(\mathrm{MPa})\end{array}$ & $\begin{array}{c}\text { Tensile strain at ultimate } \\
\text { tensile strength }\end{array}$ & $\begin{array}{c}\text { Tensile modulus } \\
\text { of elasticity } \\
(\%)\end{array}$ \\
\hline Carbon fibres & 1 & 0.167 & 22.75 & 3726 & 1.55 & 240.43 \\
\hline
\end{tabular}

781 
Table 4: Experimental results of the concentrically and eccentrically loaded specimens

\begin{tabular}{|c|c|c|c|c|c|c|c|c|c|c|}
\hline Specimen & Eccentricity & $\begin{array}{c}\text { Yield } \\
\text { axial } \\
\text { load } \\
P_{y} \\
(\mathrm{kN})\end{array}$ & $\begin{array}{c}\text { Axial } \\
\text { deformation } \\
\text { at } P_{y} \\
(\mathrm{~mm})\end{array}$ & $\begin{array}{l}\text { Ultimate } \\
\text { axial } \\
\text { load } P_{u l t} \\
(\mathrm{kN})\end{array}$ & $\begin{array}{c}\text { Axial } \\
\text { deformation } \\
\text { at } P_{u l t}(\mathrm{~mm})\end{array}$ & $\begin{array}{l}\text { Lateral } \\
\text { deformation } \\
\text { at } P_{\text {ult }}(\mathrm{mm})\end{array}$ & $\begin{array}{c}\text { Axial } \\
\text { deformation } \\
\text { at } 0.85 P_{u l t} \\
(\mathrm{~mm})\end{array}$ & $\begin{array}{c}\text { Ductility } \\
\lambda\end{array}$ & $\begin{array}{l}\text { Increase } \\
\text { in } P_{u l t} \\
\text { relative } \\
\text { to the } \\
\text { reference } \\
\text { specimen } \\
\quad(\%)\end{array}$ & $\begin{array}{c}\text { Increase } \\
\text { in } \lambda \\
\text { relative } \\
\text { to the } \\
\text { reference } \\
\text { specimen } \\
(\%)\end{array}$ \\
\hline $\mathrm{R}-0$ & & 902 & 2.17 & 993.5 & 2.76 & - & 3.15 & 1.86 & - & - \\
\hline $\mathrm{P}-0$ & 0 & 990 & 2.46 & 1114.2 & 4.68 & - & 14.25 & 9.3 & 12.1 & 400 \\
\hline $\mathrm{F}-0$ & & 993 & 2.55 & 1614.5 & 20.68 & - & 21.29 & 18.96 & 62.5 & 919.4 \\
\hline $\mathrm{R}-15$ & & 687 & 1.93 & 731.8 & 2.24 & 2.46 & 2.41 & 1.48 & - & - \\
\hline P-15 & 15 & 733.2 & 2.07 & 802.3 & 2.8 & 3.21 & 5.9 & 4.51 & 9.6 & 204.7 \\
\hline F-15 & & 900 & 2.6 & 1006.2 & 4.16 & 7.83 & 13.1 & 8.56 & 37.5 & 478.4 \\
\hline $\mathrm{R}-25$ & & 595.4 & 1.85 & 630.2 & 2.19 & 2.52 & 2.46 & 1.61 & - & - \\
\hline $\mathrm{P}-25$ & 25 & 665.8 & 2.08 & 684.93 & 2.58 & 3.42 & 4.55 & 3.24 & 8.6 & 101.2 \\
\hline F-25 & & 791.6 & 2.73 & 876.6 & 4.26 & 5.79 & 11.27 & 6.73 & 39.1 & 318 \\
\hline
\end{tabular}


Table 5: Experimental results of specimens tested under four-point bending

\begin{tabular}{|c|c|c|c|c|c|c|c|c|}
\hline Specimen & $\begin{array}{c}\text { Yield load } \\
P_{y}(\mathrm{kN})\end{array}$ & $\begin{array}{l}\text { Midspan } \\
\text { deflection } \\
\text { at } P_{y} \\
(\mathrm{~mm})\end{array}$ & $\begin{array}{l}\text { Ultimate } \\
\text { load } P_{u l t} \\
(\mathrm{kN})\end{array}$ & $\begin{array}{c}\text { Midspan } \\
\text { deflection } \\
\text { at } P_{u l t}(\mathrm{~mm})\end{array}$ & $\begin{array}{c}\text { Midspan } \\
\text { deflection } \\
\text { at } 0.85 P_{\text {ult }} \\
(\mathrm{mm})\end{array}$ & $\begin{array}{c}\text { Ductility } \\
\lambda\end{array}$ & $\begin{array}{l}\text { Increase in } P_{u l t} \\
\text { relative to the } \\
\text { reference } \\
\text { specimen }(\%)\end{array}$ & $\begin{array}{l}\text { Increase in } \lambda \\
\text { relative to the } \\
\text { reference } \\
\text { specimen }(\%)\end{array}$ \\
\hline R-B & 111.08 & 3.5 & 126.1 & 6.11 & 56.44 & 27.4 & - & - \\
\hline P-B & 111.03 & 3.5 & 155.9 & 24.46 & 36.84 & 28.1 & 23.6 & 2.6 \\
\hline F-B & 117.5 & 3.25 & 189.33 & 34.81 & 43.1 & 32.92 & 50.1 & 20.1 \\
\hline
\end{tabular}

785 
787 Table 6: Experimental axial load and bending moment interactions of the tested specimens

\begin{tabular}{ccccc}
\hline Group & Specimen & $\begin{array}{c}\text { Ultimate axial load } \\
(\mathrm{kN})\end{array}$ & $\begin{array}{c}\text { Lateral deformation at } \\
\text { ultimate axial load }(\mathrm{mm})\end{array}$ & $\begin{array}{c}\text { Maximum bending moment } \\
(\mathrm{kN} . \mathrm{m})\end{array}$ \\
\hline $\mathrm{R}$ & 993.5 & 0 & 0 \\
& $\mathrm{R}-0$ & 731.8 & 2.46 & 12.78 \\
& $\mathrm{R}-15$ & 630.2 & 2.52 & 17.34 \\
& $\mathrm{R}-25$ & 126.1 & 6.11 & 14.69 \\
\hline & R-B & 1114.2 & 0 & 14.61 \\
$\mathrm{P}$ & P-0 & 802.3 & 3.21 & 19.46 \\
& P-15 & 684.9 & 3.42 & 18.16 \\
& P-25 & 155.9 & 24.46 & 0 \\
& P-B & 1614.5 & 0 & 22.97 \\
& F-0 & 1006.2 & 7.83 & 26.99
\end{tabular}



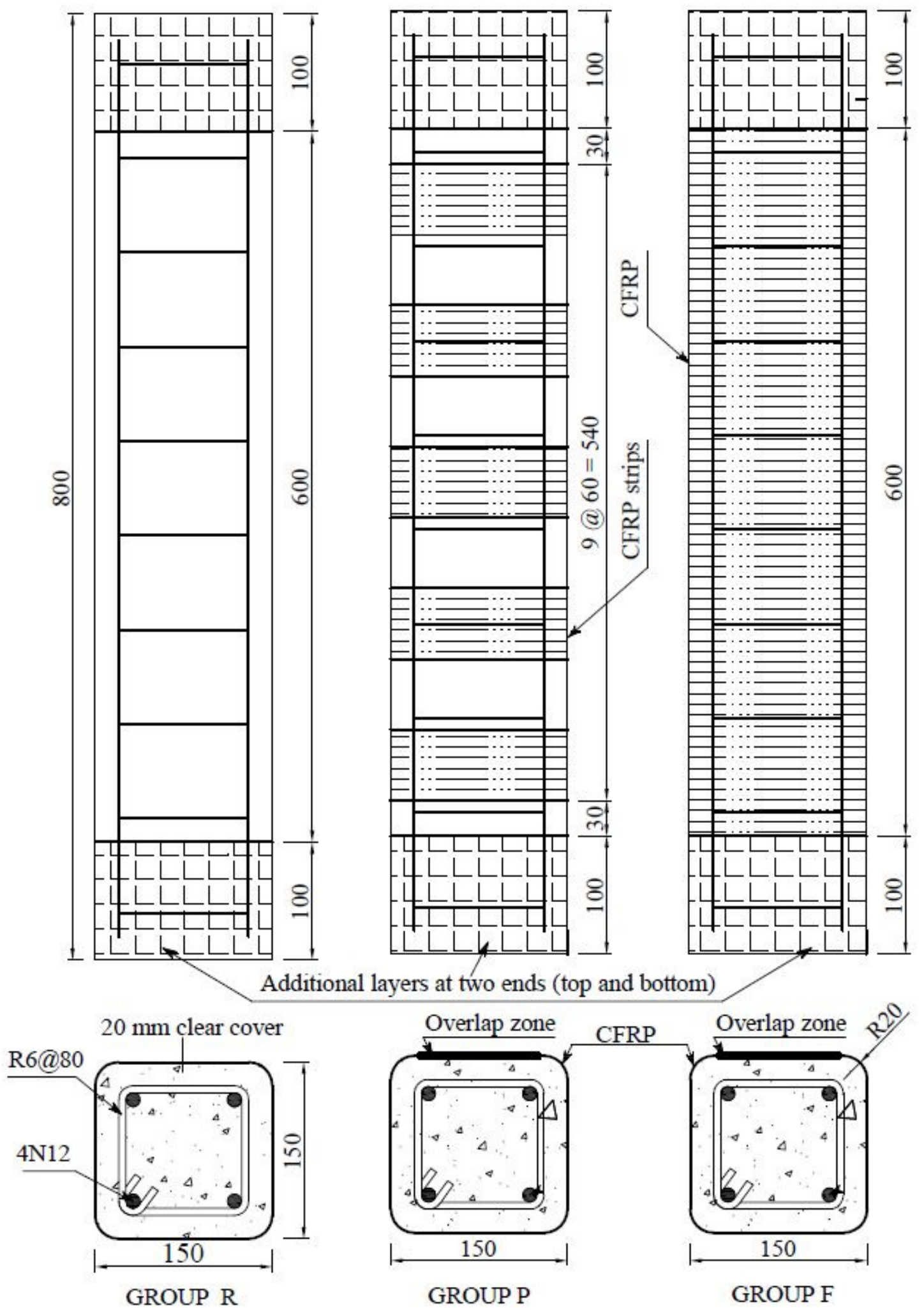

Figure 1: Details of the geometry and reinforcement of RC specimens (All dimensions are in $\mathrm{mm}$ ) 


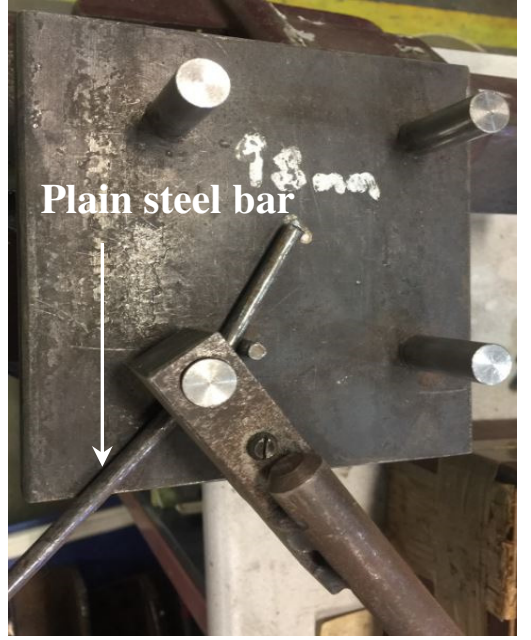

(a)

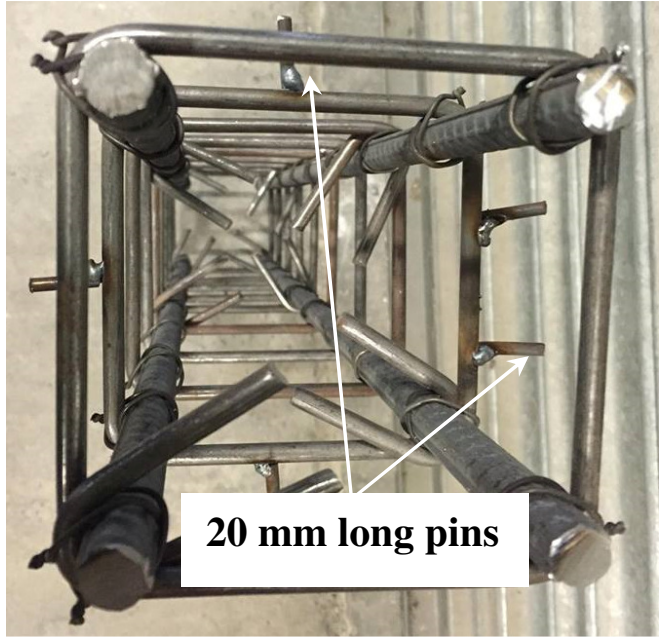

(b)

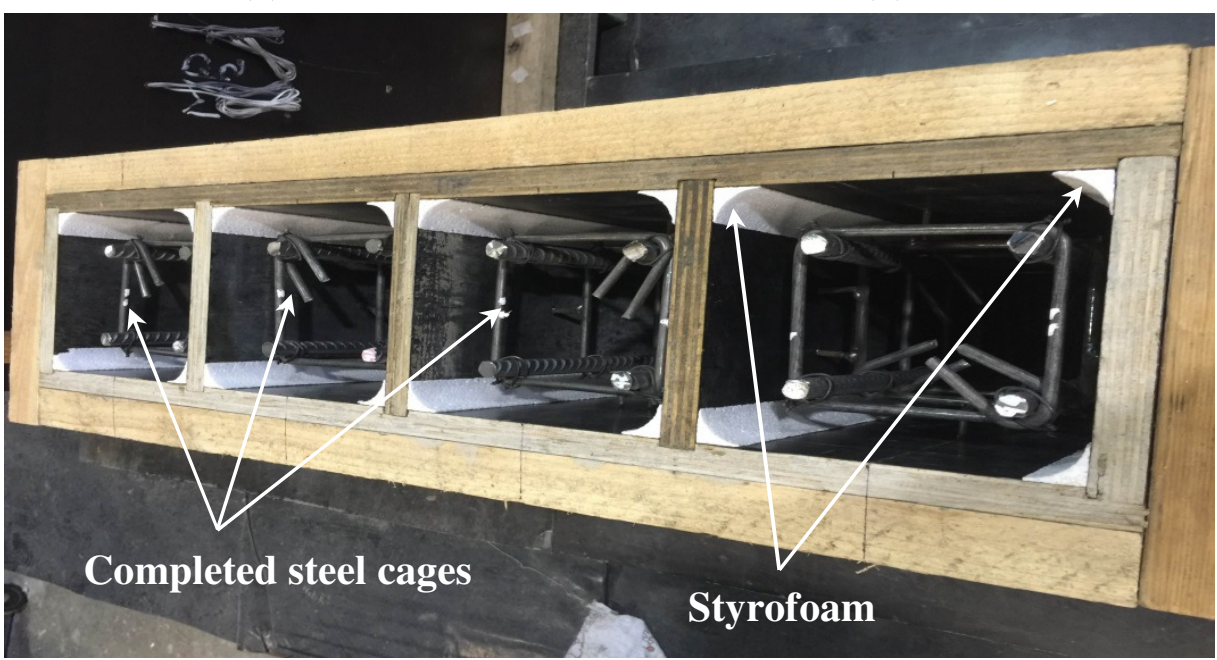

(d)

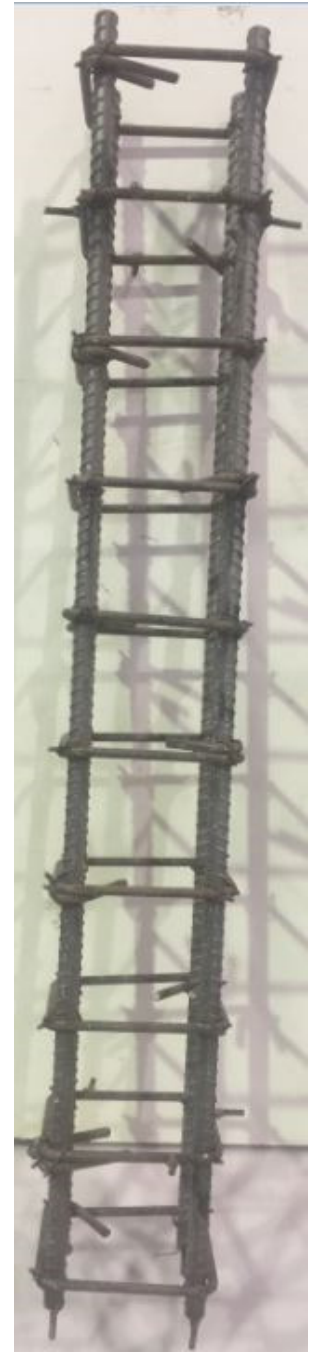

(c)

Figure 2: Details of steel cages and formworks: (a) steel tie bending equipment, (b) plan view of completed steel cage, (c) elevation of completed steel cage, and (d) formwork before casting of concrete 


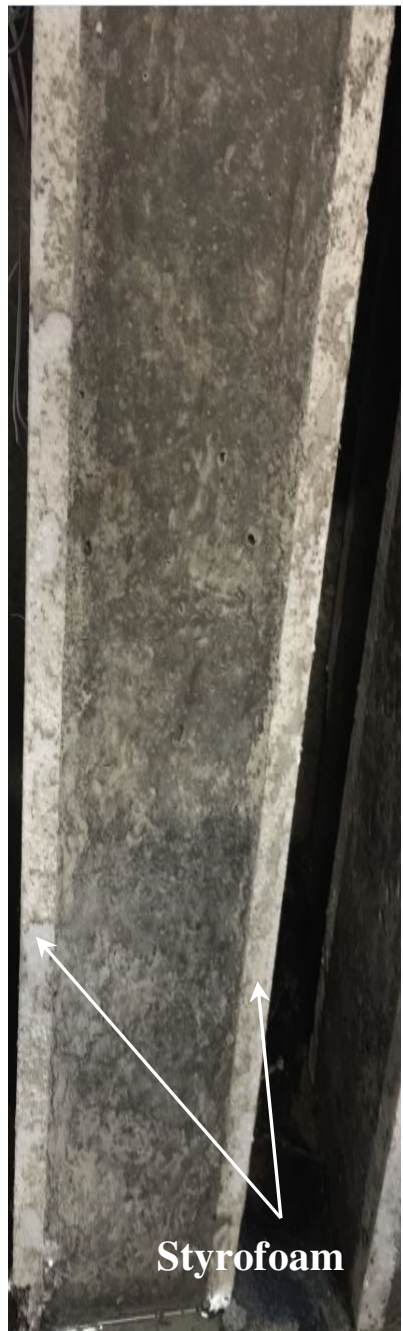

(a)

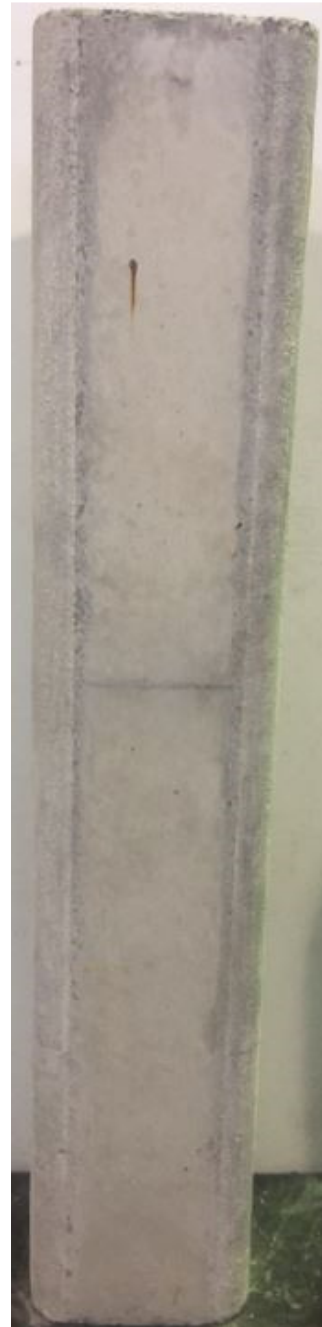

(b)

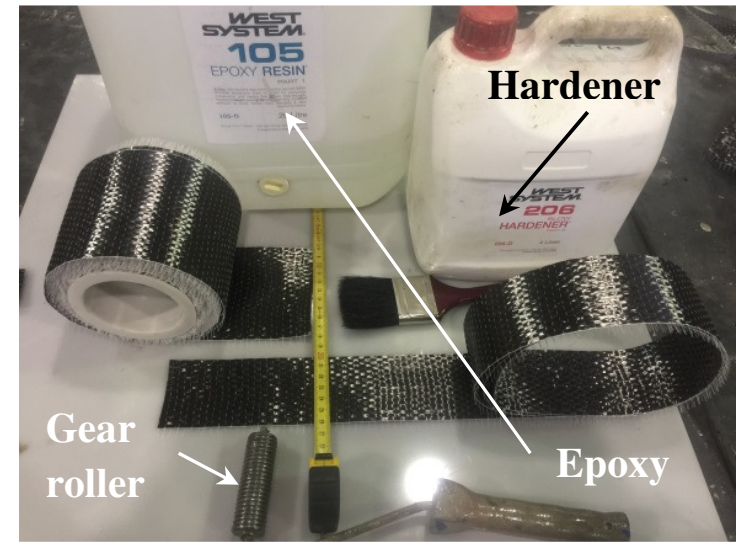

(c)

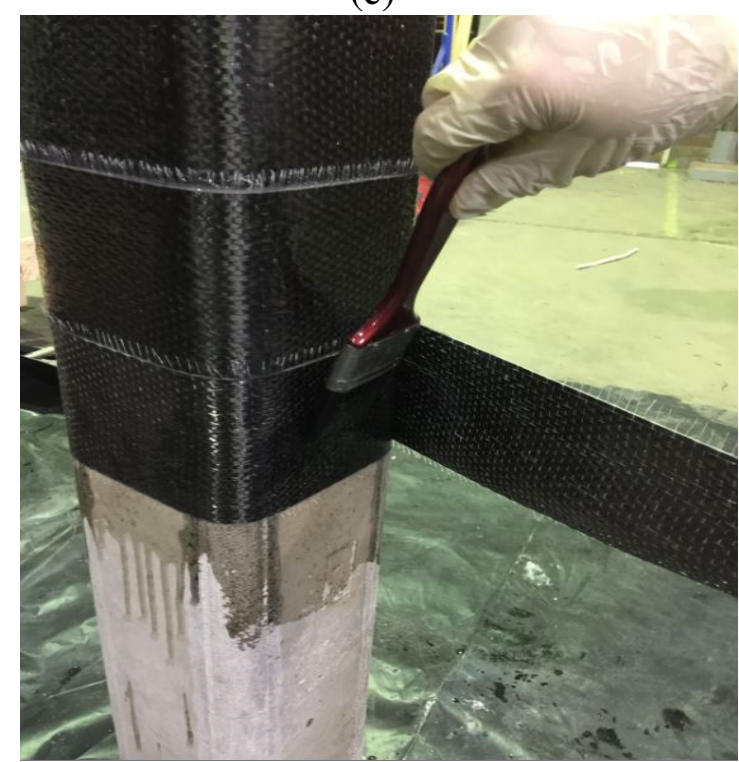

(d)

797 Figure 3: Details of wrapping procedure: (a) specimen before cleaning, (b) specimen before wrapping, (c) wrapping materials and equipment, and (d) wet lay-up technique for wrapping 


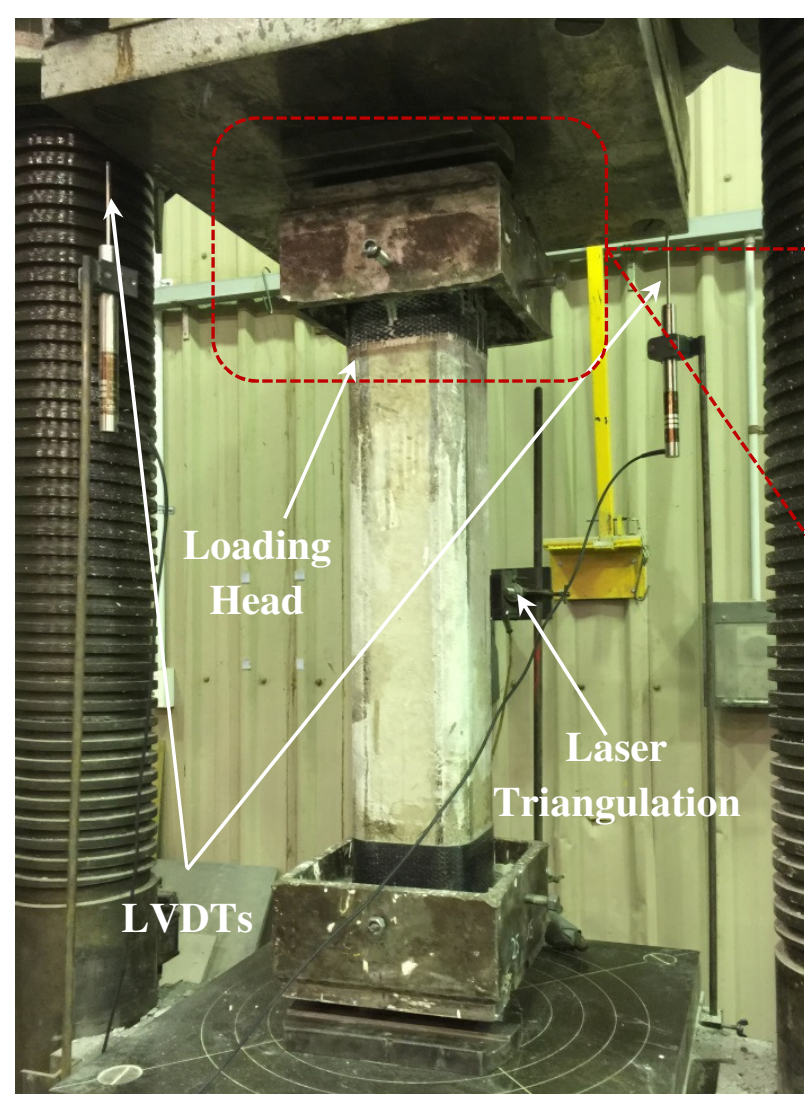

(a)

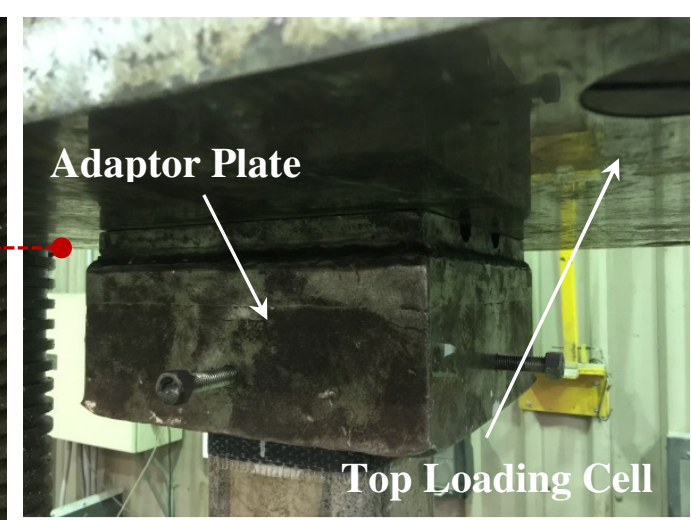

(b)

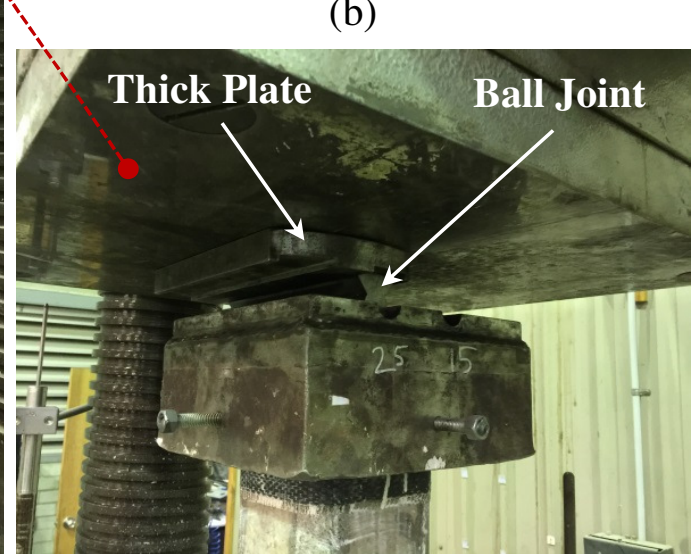

(c)

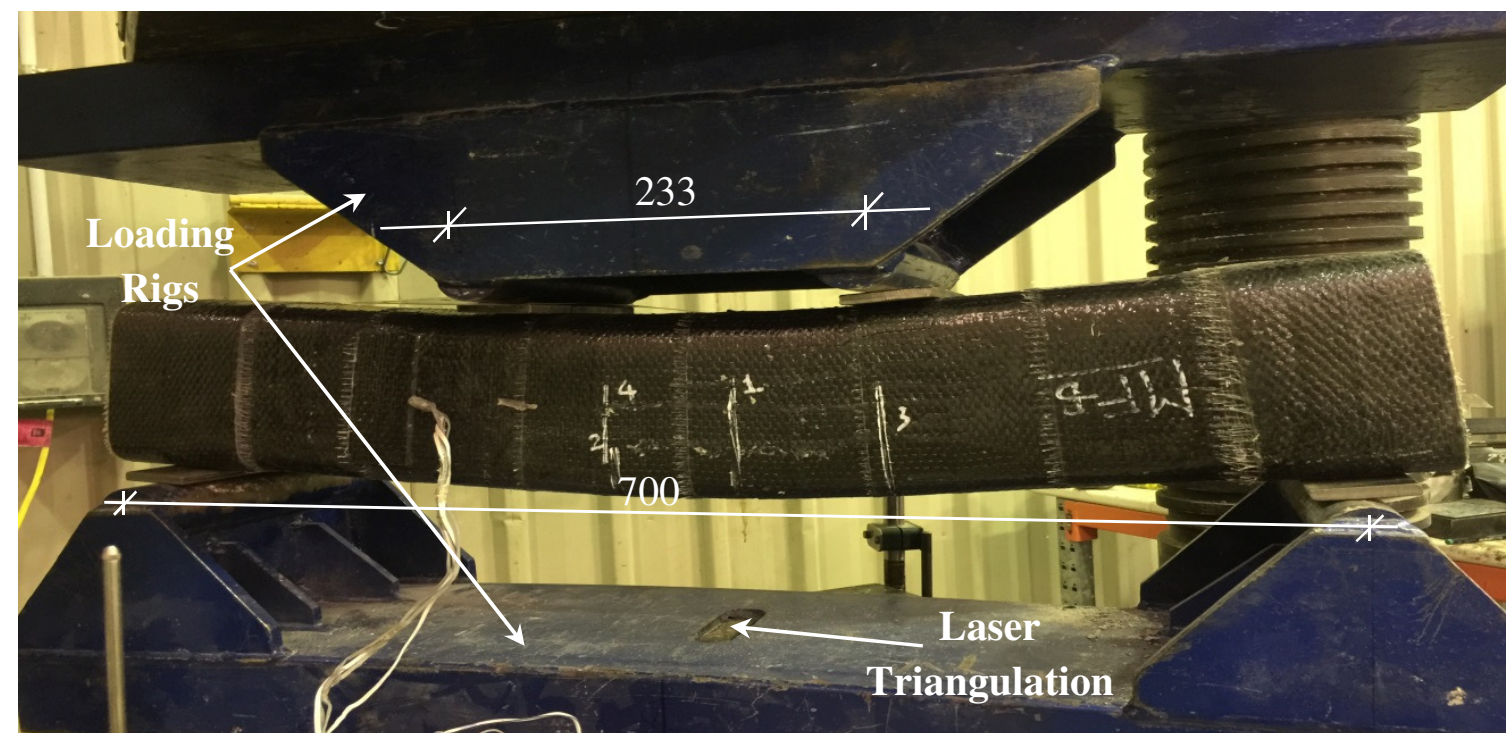

(d)

$801 \quad$ Figure 4: Loading system and instruments: (a) test setup of the column specimens, (b)

802 loading head system for concentrically loaded specimens, (c) loading head system for eccentrically loaded specimens, and (d) test setup of the beam specimens 
804

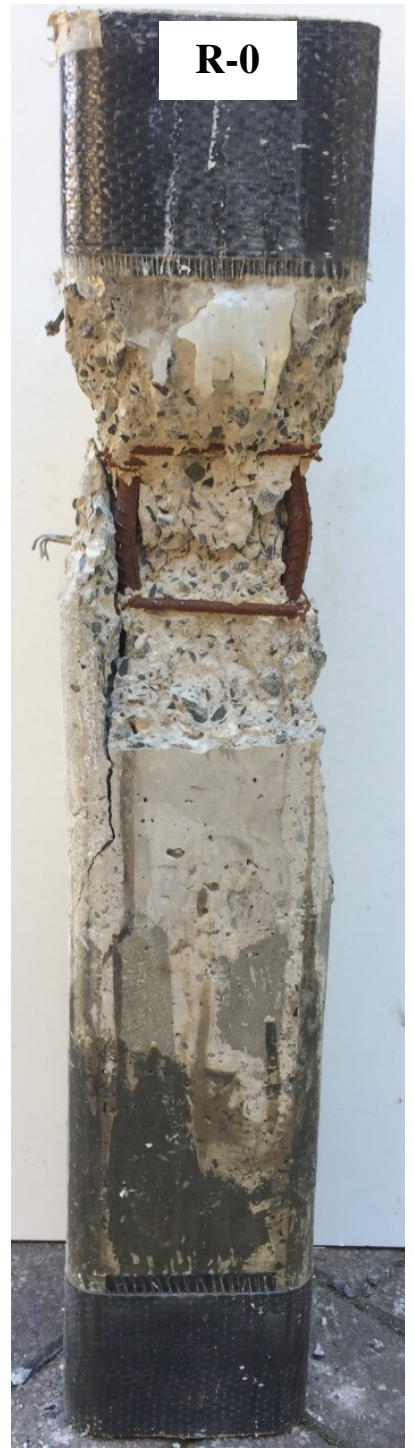

(a)

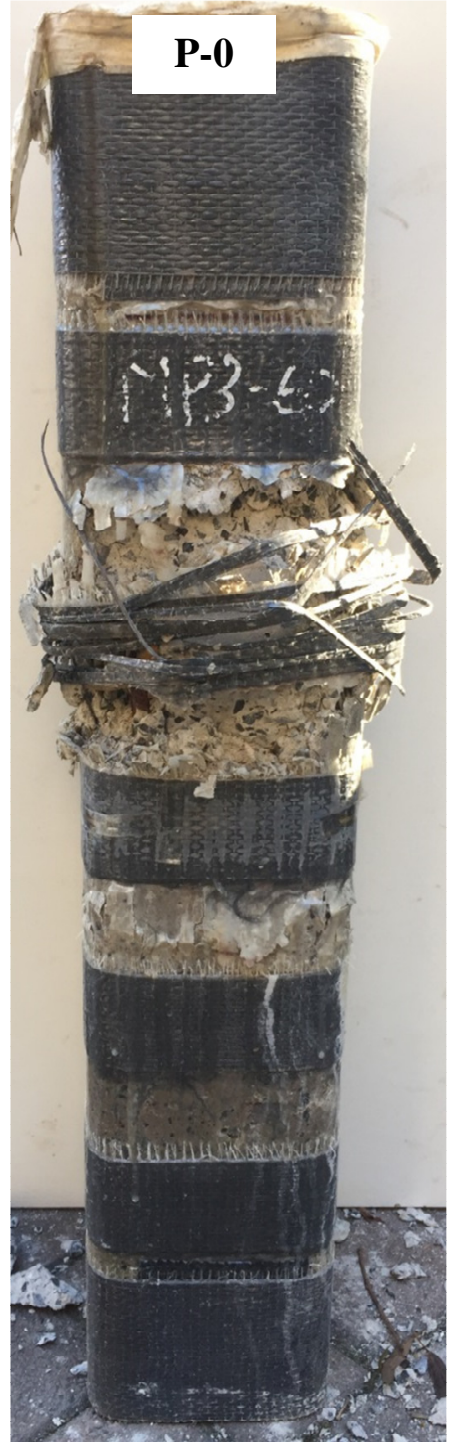

(b)

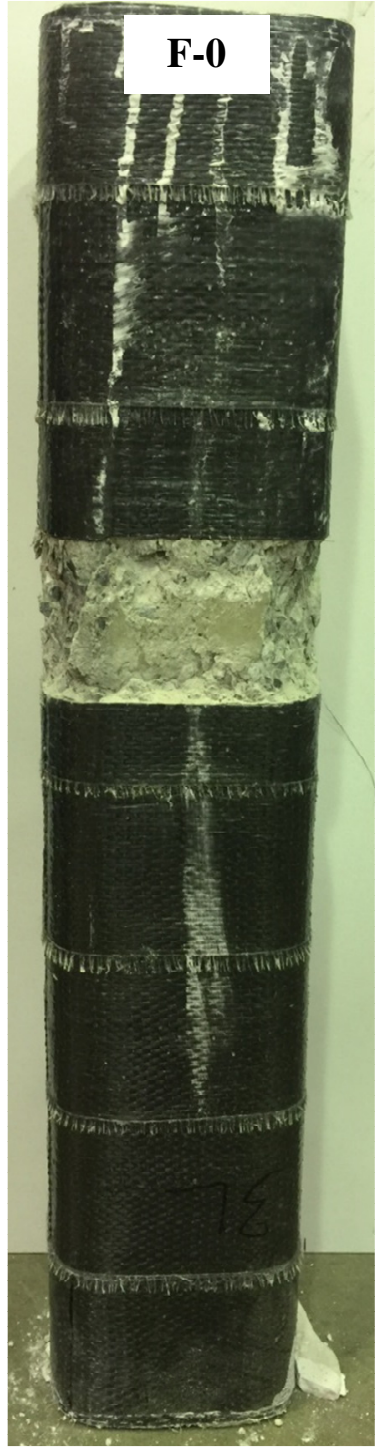

(c)
805

806

Figure 5: Failure modes of specimens tested under concentric axial load: (a) Specimen R-0, (b) Specimen P-0, and (c) Specimen F-0 


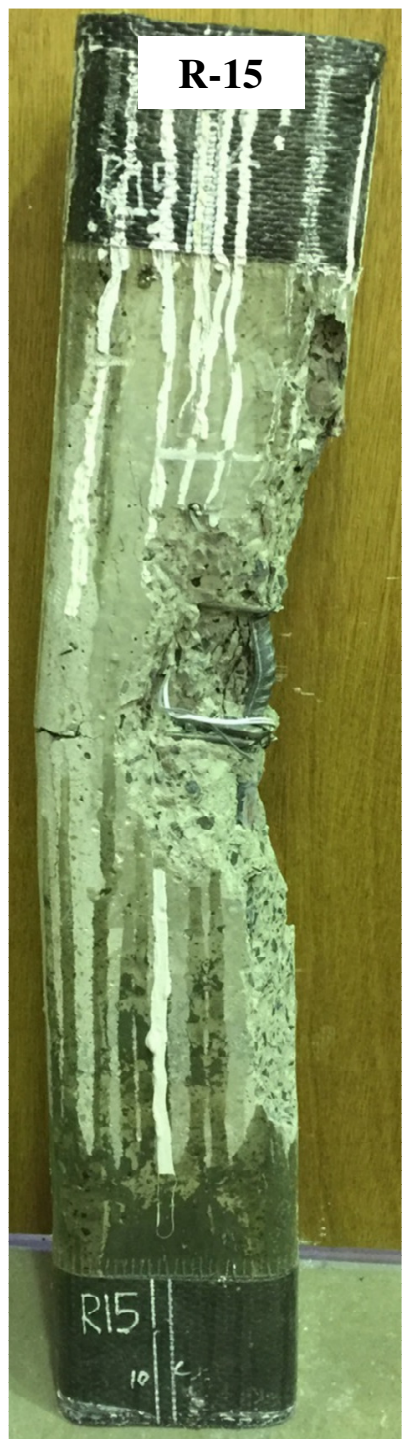

(a)

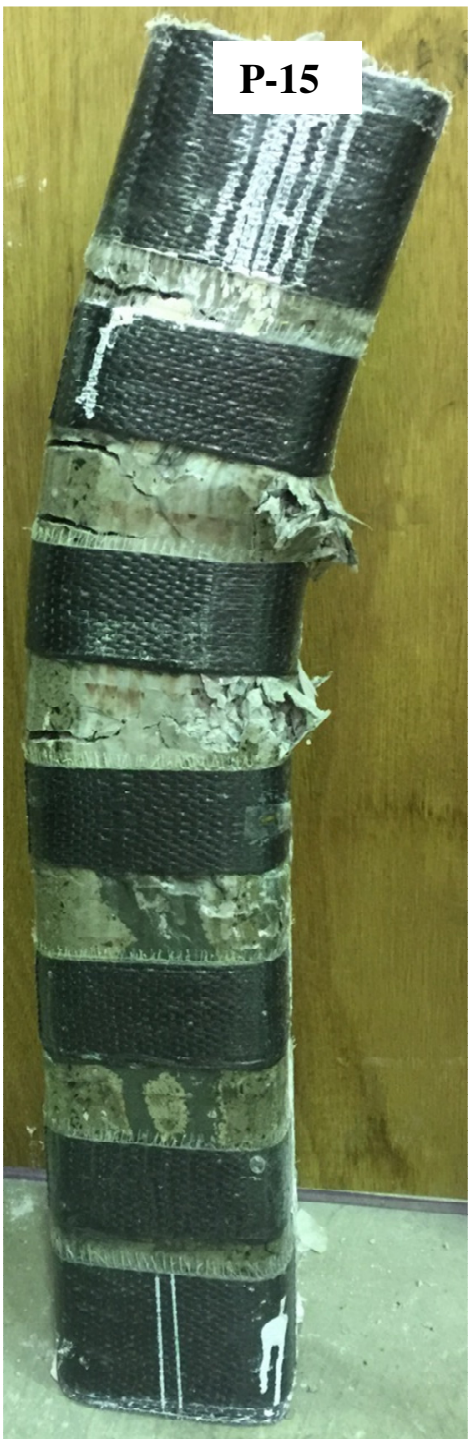

(b)

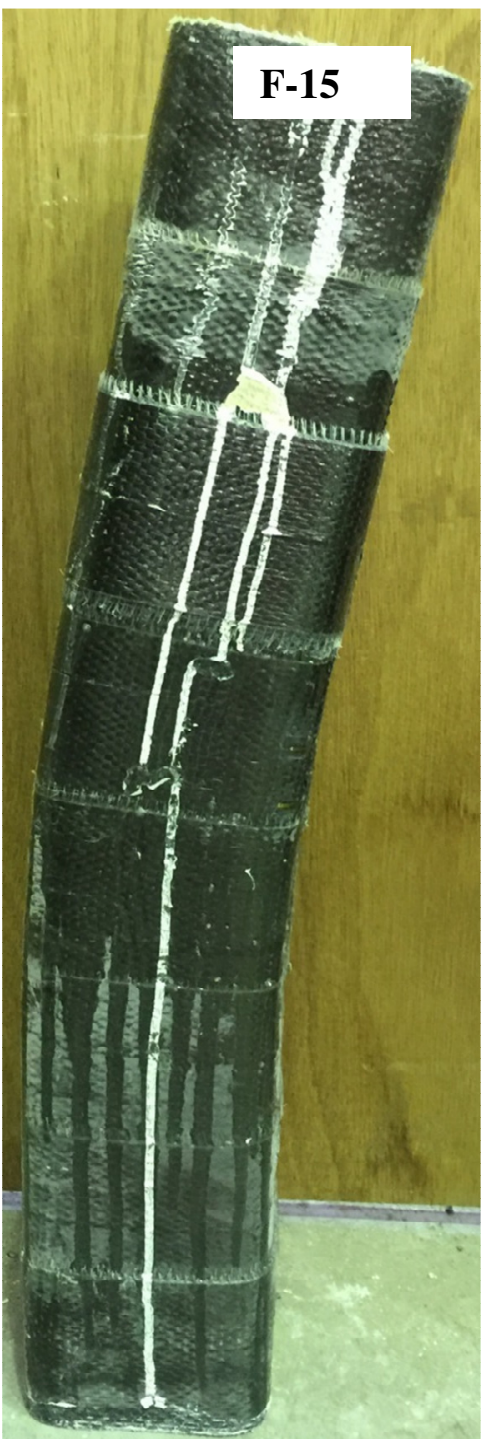

(c)

Figure 6: Failure modes of specimens tested under $15 \mathrm{~mm}$ eccentric axial load: (a) Specimen R-15, (b) Specimen P-15, and (c) Specimen F-15 


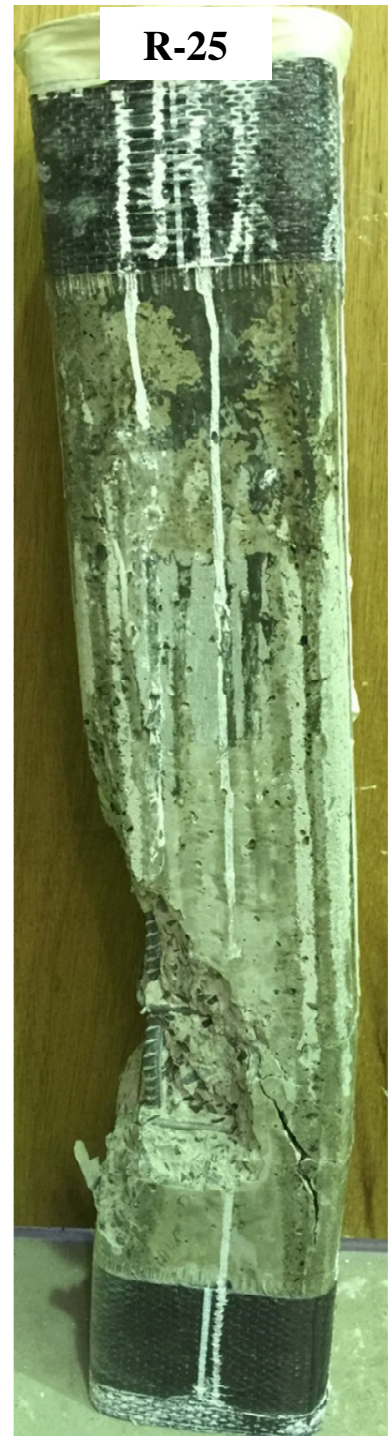

(a)

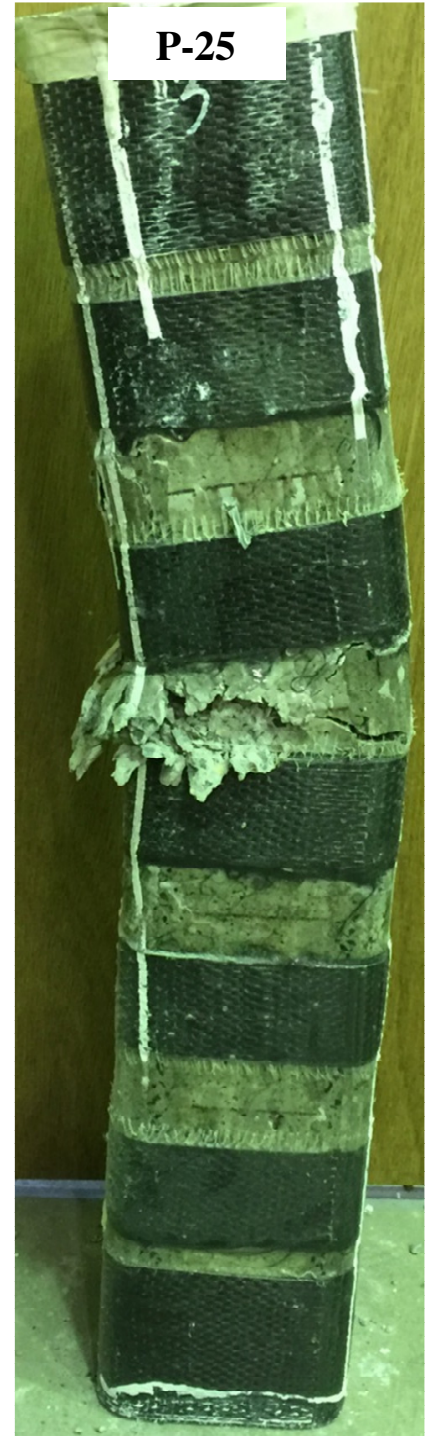

(b)

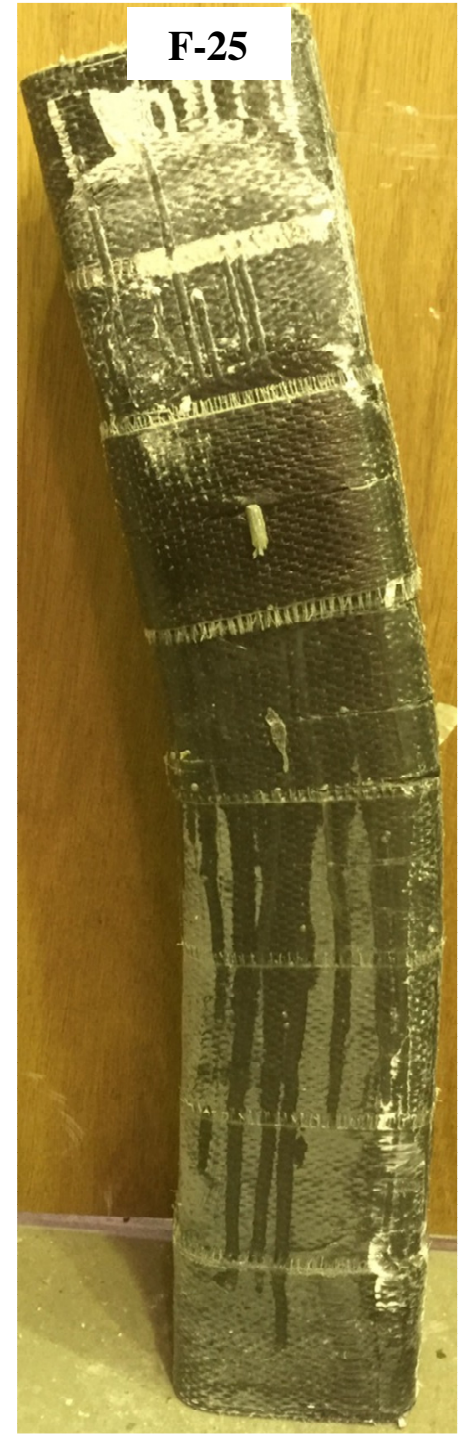

(c)

812 Figure 7: Failure modes of specimens tested under $25 \mathrm{~mm}$ eccentric axial load: (a) Specimen R-25, (b) Specimen P-25, and (c) Specimen F-25 


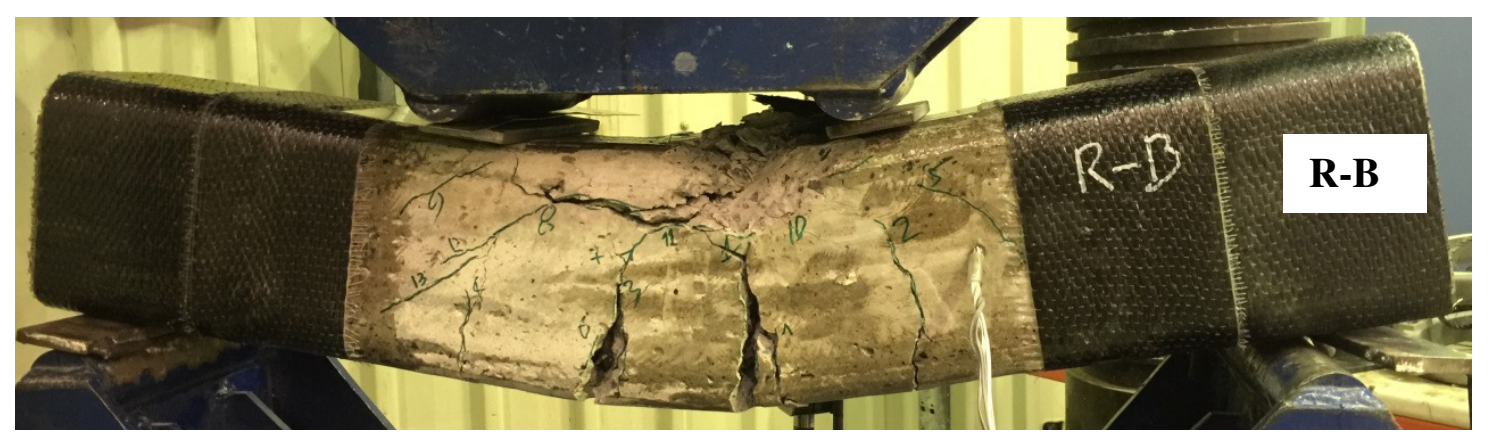

(a)

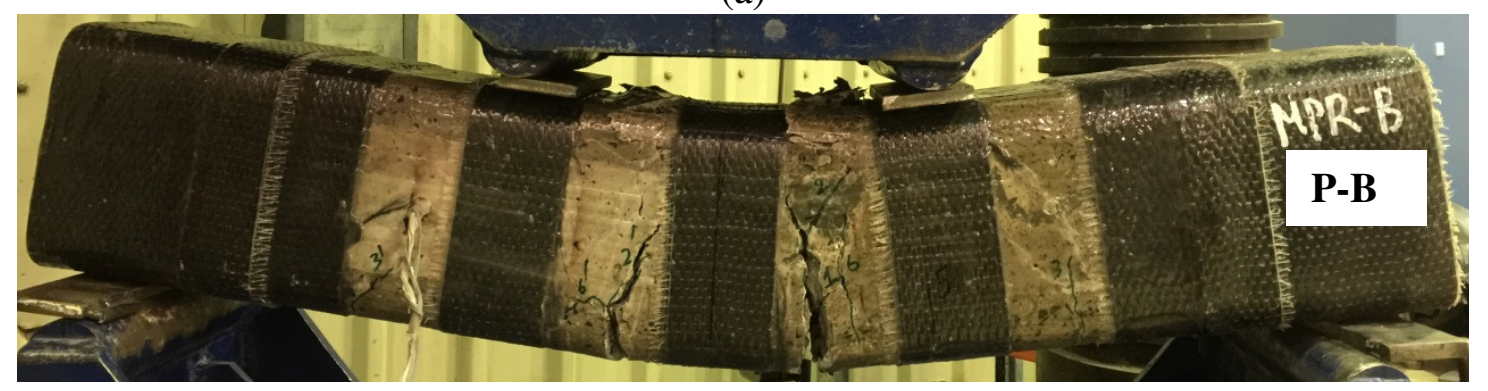

(b)

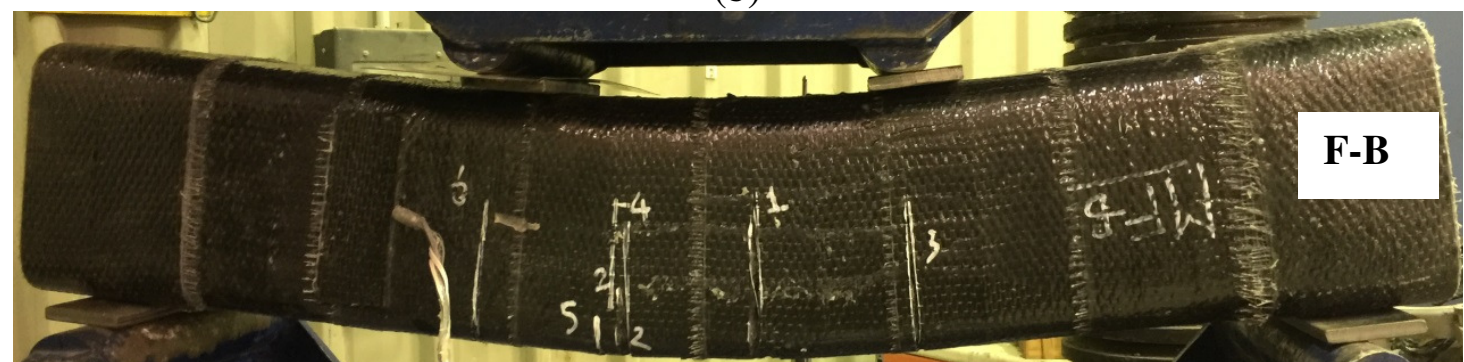

(c)

814 Figure 8: Failure modes of specimens tested under four-point bending: (a) Specimen RB, (b) Specimen P-B, and (c) Specimen F-B 


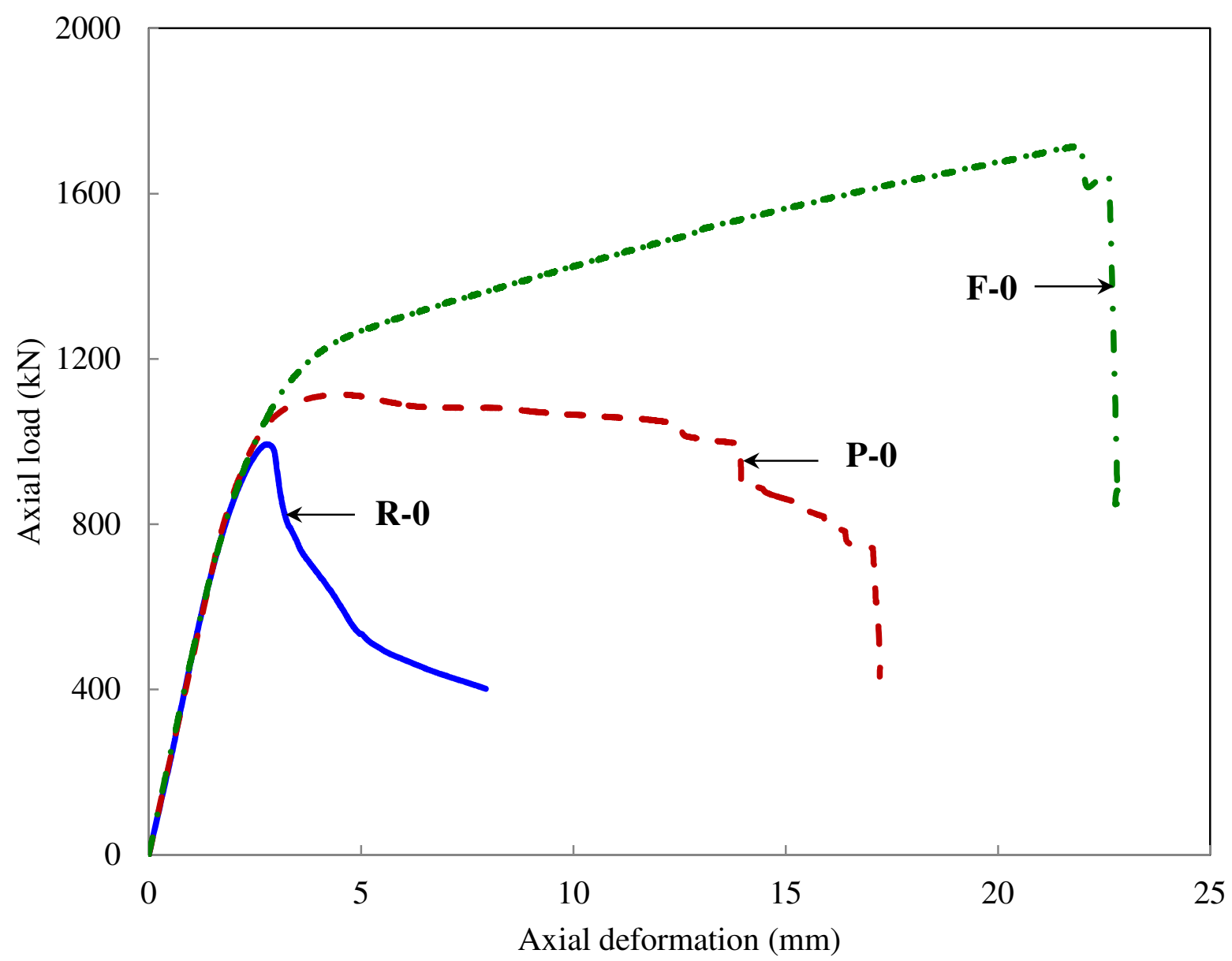




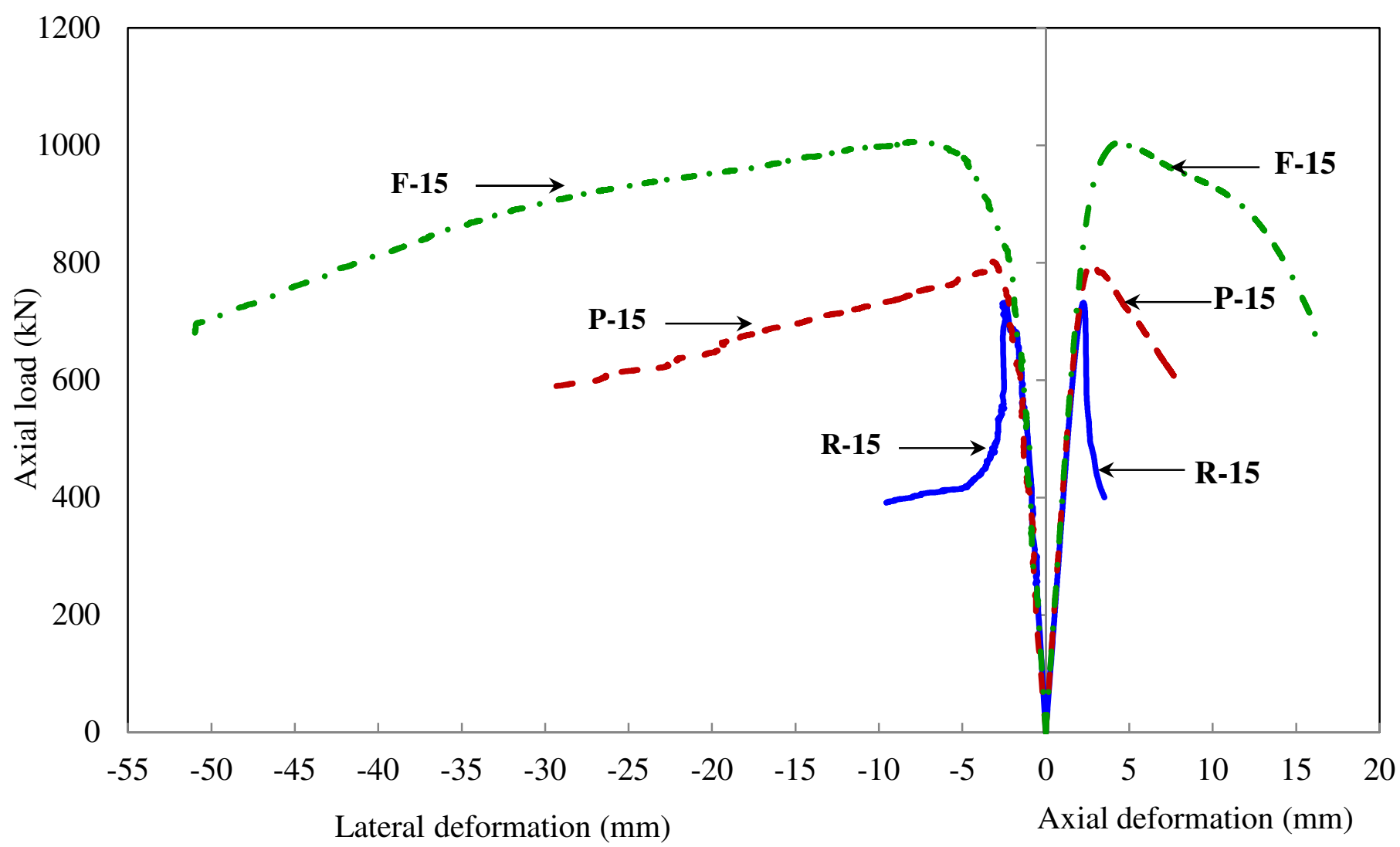

Figure 10: Axial load-axial deformation and axial load-lateral deformation behaviour of specimens tested under $15 \mathrm{~mm}$ eccentric axial 


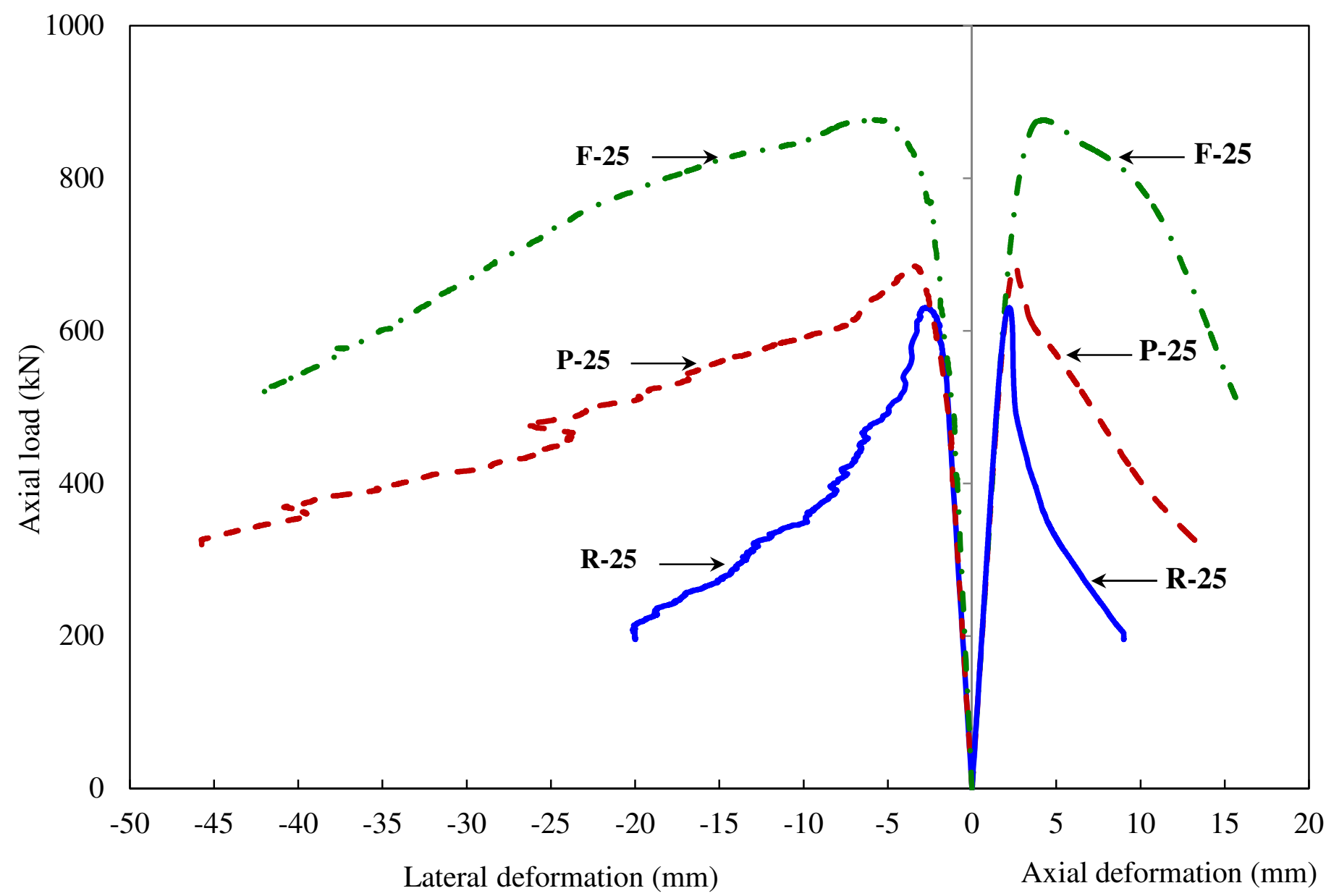

Figure 11: Axial load-axial deformation and axial load-lateral deformation behaviour of specimens tested under $25 \mathrm{~mm}$ eccentric axial load 


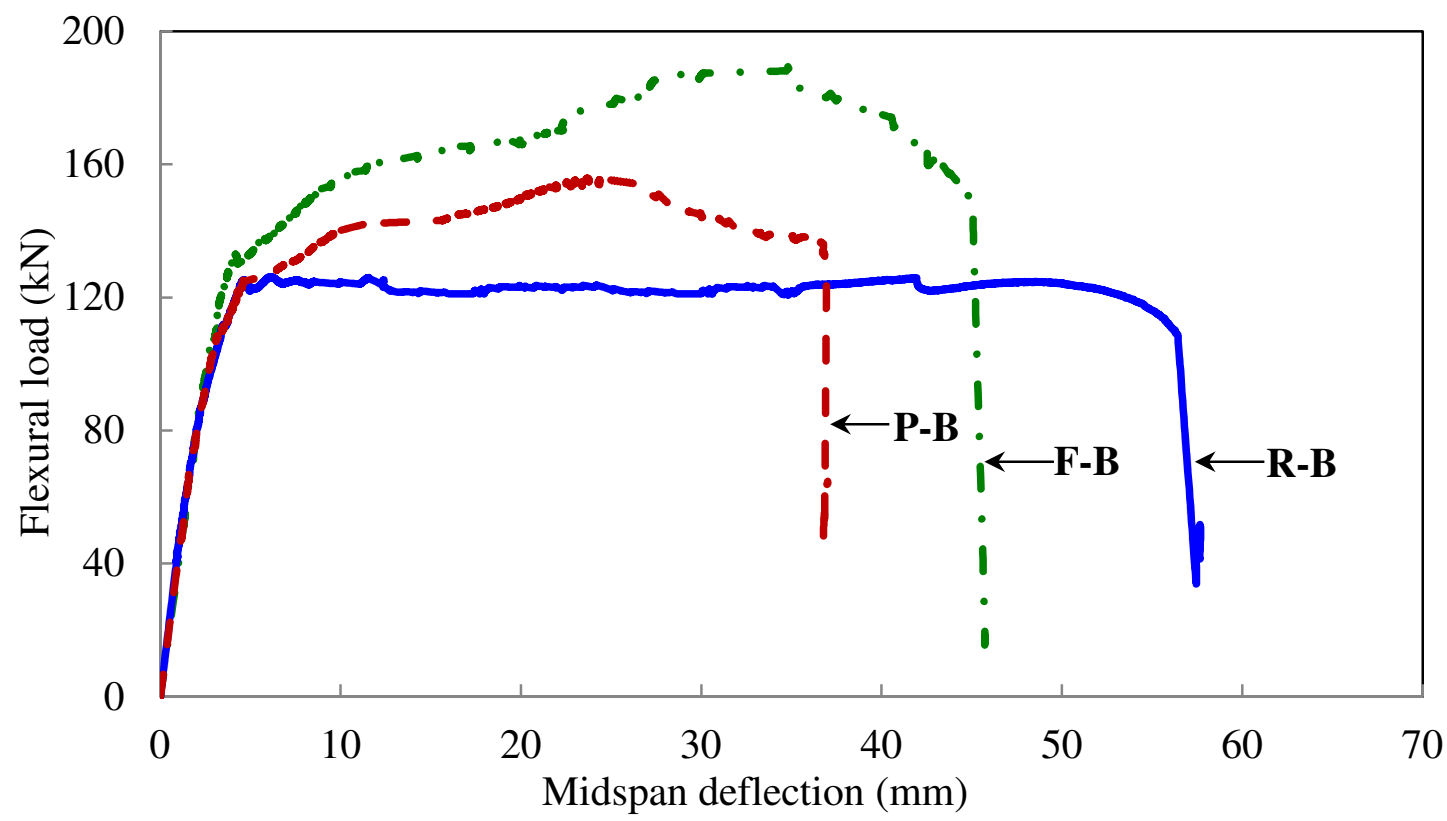

Figure 12: Flexural load-midspan deflection behaviour of specimens tested under four-point bending 


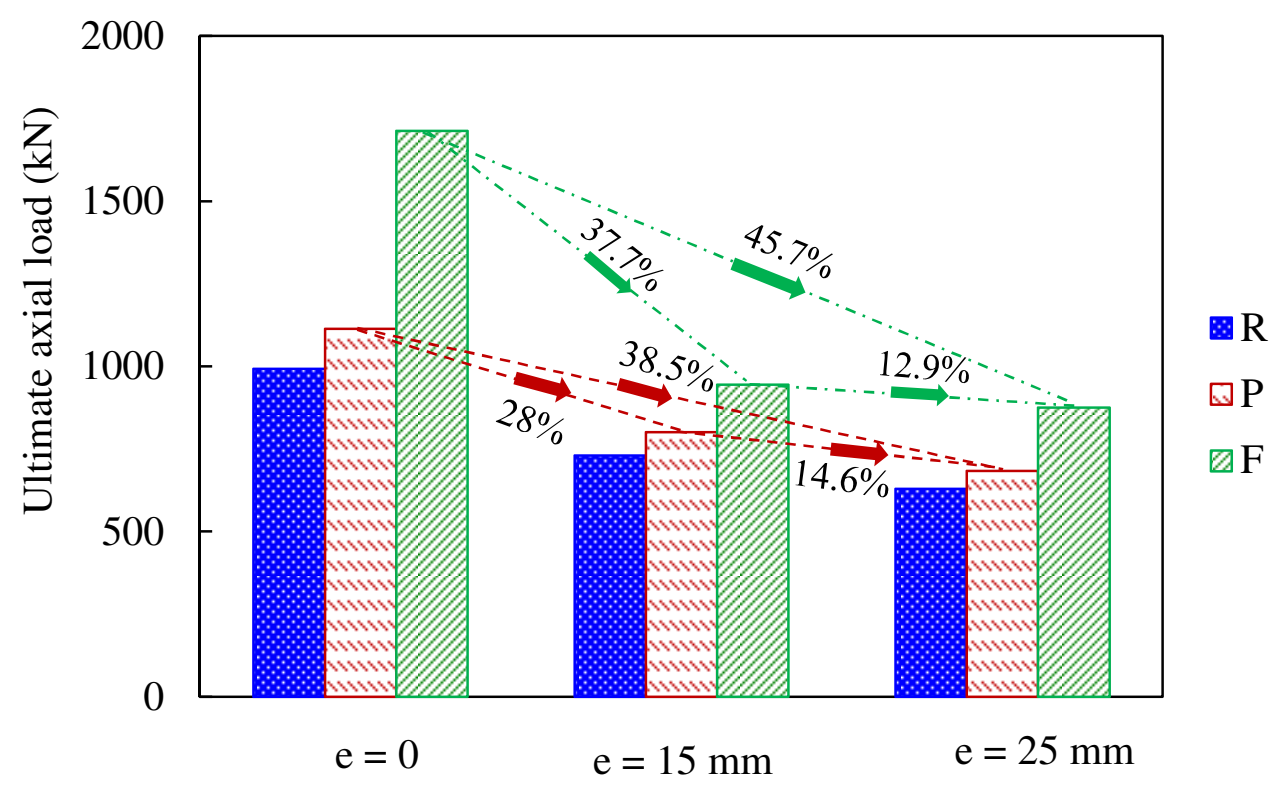

(a) Ultimate axial load versus eccentricity

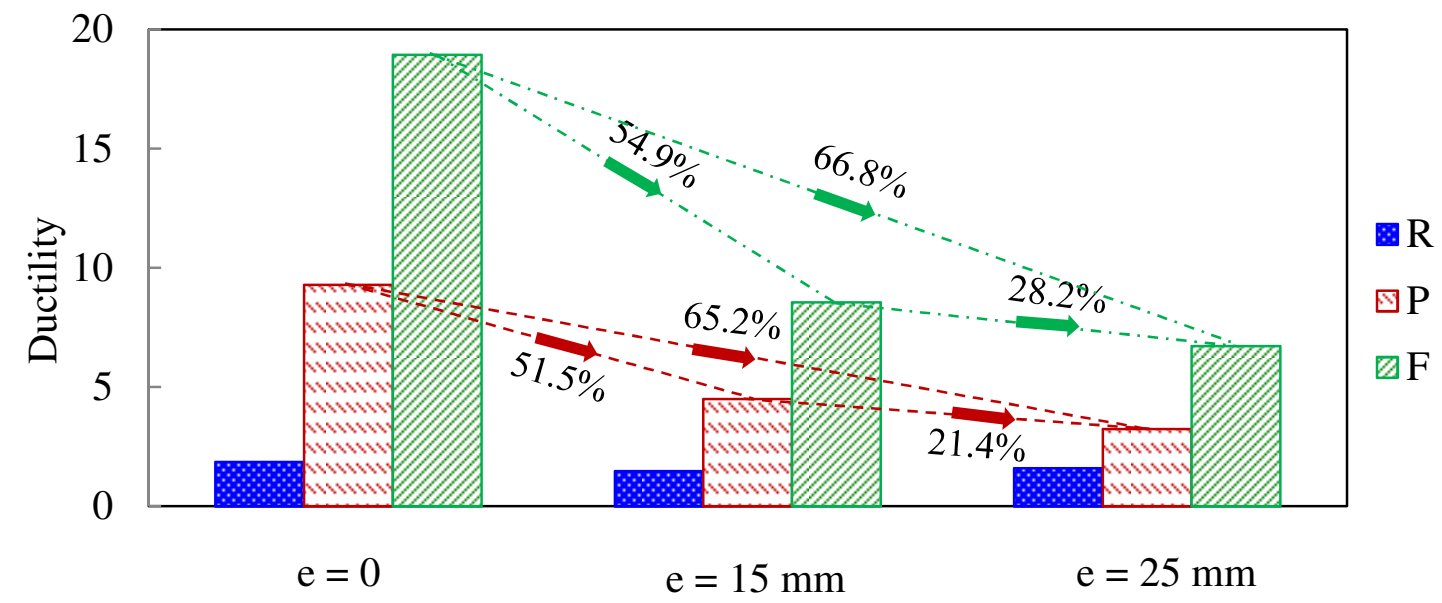

(b) Ductility versus eccentricity

Figure 13: Effect of axial load eccentricity: (a) Ultimate axial load vs eccentricity and

(b) Ductility vs eccentricity 


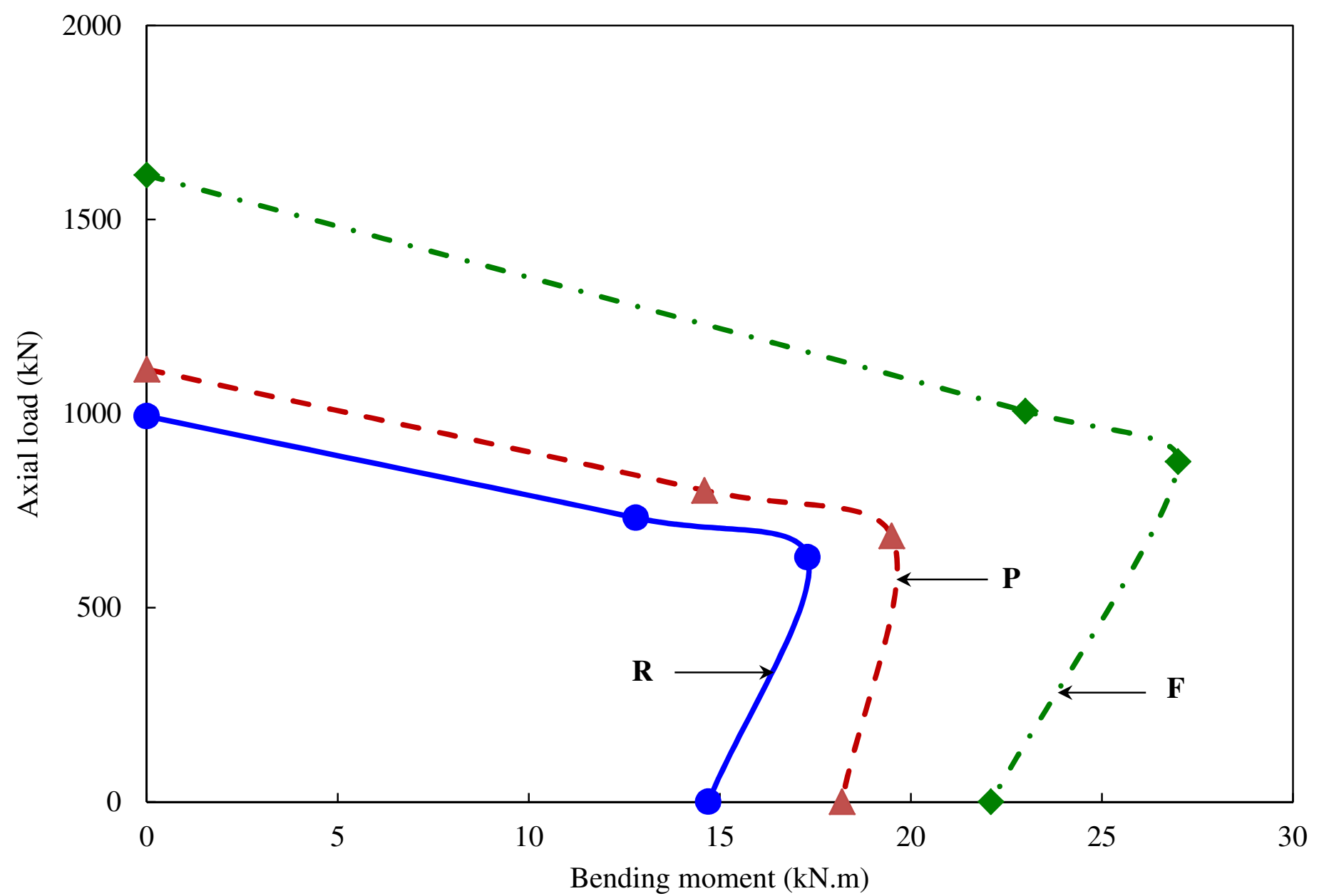

Figure 14: Experimental axial load-bending moment interaction diagram 